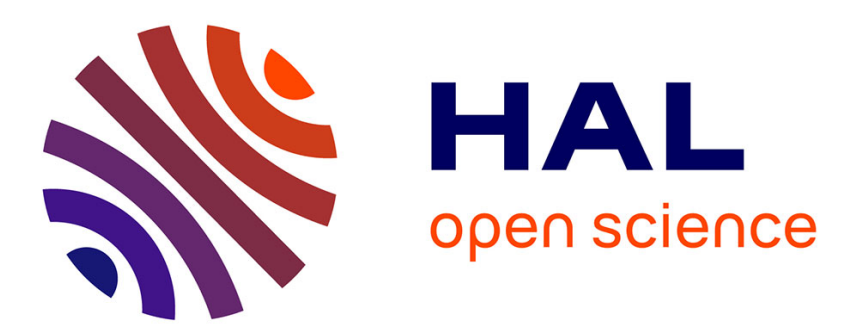

\title{
Electronic-Specific Modeling of Nitric Oxide in a Recombining Air Plasma
}

Ulysse Dubuet, Pierre Mariotto, Marie-Yvonne Perrin, Christophe O Laux

\section{To cite this version:}

Ulysse Dubuet, Pierre Mariotto, Marie-Yvonne Perrin, Christophe O Laux. Electronic-Specific Modeling of Nitric Oxide in a Recombining Air Plasma. AIAA Scitech 2021 Forum, Jan 2021, VIRTUAL EVENT, France. 10.2514/6.2021-0445 . hal-03117353

\section{HAL Id: hal-03117353 \\ https://hal.science/hal-03117353}

Submitted on 15 Mar 2021

HAL is a multi-disciplinary open access archive for the deposit and dissemination of scientific research documents, whether they are published or not. The documents may come from teaching and research institutions in France or abroad, or from public or private research centers.
L'archive ouverte pluridisciplinaire HAL, est destinée au dépôt et à la diffusion de documents scientifiques de niveau recherche, publiés ou non, émanant des établissements d'enseignement et de recherche français ou étrangers, des laboratoires publics ou privés. 


\title{
Electronic-Specific Modeling of Nitric Oxide in a Recombining Air Plasma
}

\author{
Ulysse Dubuet, ${ }^{*}$ Pierre Mariotto', \\ Marie-Yvonne Perrin and Christophe O. Laux \\ Laboratoire EM2C, CNRS UPR 288, CentraleSupélec, Université Paris-Saclay, 3 rue Joliot- \\ Curie, Gif-sur-Yvette, France
}

\begin{abstract}
An electronic-specific collisional-radiative (CR) model of Nitric Oxide (NO) is presented and applied to the study of a recombining air plasma. This plasma is produced at local thermodynamic equilibrium at $8000 \mathrm{~K}$ and $1 \mathrm{~atm}$ by a $50-\mathrm{kW}$ Inductively Coupled Plasma torch and passes at high-velocity through a water-cooled tube that forces rapid cooling and recombination. The electronic-specific model takes into account $\mathrm{NO}\left(\mathrm{C}^{2} \Pi\right)$ predissociation, spontaneous emission from the $C^{2} \Pi$ and $D^{2} \Sigma^{+}$states towards the $A^{2} \Sigma^{+}$state, and quenching of the excited states by various colliders. This model, alongside two other electronic-specific CR models developed for NO at NASA, is compared to measurements of NO excited states and electron densities along the tube length. Better agreement is obtained with the model presented in this work, especially because of the $\mathrm{NO}\left(\mathrm{C}^{2} \Pi\right)$ predissociation and $\mathrm{NO} \mathrm{C}^{2} \Pi$ and $\mathrm{D}^{2} \Sigma^{+}$ spontaneaous emission toward $\operatorname{NO}\left(\mathrm{A}^{2} \Sigma^{+}\right)$. The electron overpopulation is also explained by the partial equilibrium between $\mathrm{N}$ and $\mathrm{O}$ atoms and electrons, and the slow depletion of $\mathrm{N}$ and $O$ atoms by the NO recombination reactions.
\end{abstract}

\section{Introduction}

$\mathrm{D}$ uring atmospheric entry, a vehicle experiences a significant radiative heat flux due to the shock layer that forms in front of the capsule. Designing the heat shield requires to accurately determine the heat load on the spacecraft. While the prediction of the radiative heat flux to the forebody has been thoroughly investigated, the prediction of radiation on the afterbody still suffers from large uncertainties [1,2]. Indeed, the recombination kinetics in the afterbody region are complex and lead to non-equilibrium population distributions of the strongest radiative species. This work will focus on these kinetics: the slow recombination reaction cannot accommodate the rapid hydrodynamic cooling of the gas in the afterbody wake, which leads to a departure from thermochemical equilibrium.

Experiments have been performed to acquire data representative of such recombining flows [3-6]: a plasma torch was used to heat up various mixtures of gas up to $7000-8000 \mathrm{~K}$ at equilibrium, then the gas was forced to cool rapidly while flowing through a water-cooled tube and various diagnostics were applied to quantify the non-equilibrium state of the gas at the outlet of tubes of various lengths, ranging from 10 to $65 \mathrm{~cm}$. These measurements are valuable to assess the state-of-the-art kinetic models. In [7,8], two molecular and atomic nitrogen state-to-state models were assessed against the experimental data with a nitrogen/argon mixture. The present paper extends the assessment to an air/argon mixture.

The air-argon mixture experiments were performed at Stanford and are described in Ref. [4]: at the inlet of the tube (outlet of the plasma torch) the air/argon mixture is at LTE at $8000 \mathrm{~K}$ and atmospheric pressure, then the watercooled tube forces plasma cooling to $2500 \mathrm{~K}$. The decrease in temperature is sufficiently fast (from 8000 to $2500 \mathrm{~K}$ in approximately $2 \mathrm{~ms}$ ) that the gas is out of equilibrium at the outlet of the tube. The NO excited electronic states

\footnotetext{
${ }^{*}$ Ph.D. Candidate, Laboratoire EM2C, CNRS UPR288, CentraleSupélec, Université Paris-Saclay, AIAA Member.

${ }^{\dagger}$ Ph.D. Candidate, Laboratoire EM2C, CNRS UPR288, CentraleSupélec, Université Paris-Saclay.

* Professor, Laboratoire EM2C, CNRS UPR288, CentraleSupélec, Université Paris-Saclay.

$\S$ Professor, Laboratoire EM2C, CNRS UPR288, CentraleSupélec, Université Paris-Saclay, AIAA Fellow.
} 
were found to be strong emitters of the recombining plasma and their number densities were measured by OES [4]. These measurements will serve as a reference in this work.

The widely used Park kinetic model [9] was compared to the experimental results in [4]. This model tracks the evolution of the global species and the internal states are assumed to follow Boltzmann distributions. Meanwhile, new electronic-specific kinetic models for air $[10,11]$ were developed and validated against NASA Electric Arc ShockTube (EAST) measurements in a dissociating flow. But they have not yet been assessed in a recombining flow.

In this study, we will assess the NO electronic-specific kinetic model of Refs. [10,11] by comparing their predictions to the experimental overpopulations of NO electronic states measured in the air-argon recombination experiment [4]. Then, we will present a new electronic-specific CR model for Nitric Oxide that is in better agreement with the measurements.

\section{Experimental setup}

The experimental setup is described in [4,12]. A dissociated high-temperature plasma is forced to recombine by rapid cooling. The equilibrium air/argon plasma is generated using a 50-kW ICP plasma torch facility. Then the plasma flows through a water-cooled tube (diameter $1 \mathrm{~cm}$, length ranging from 10 to $65 \mathrm{~cm}$ ) to impose fast cooling (see Figure 1).

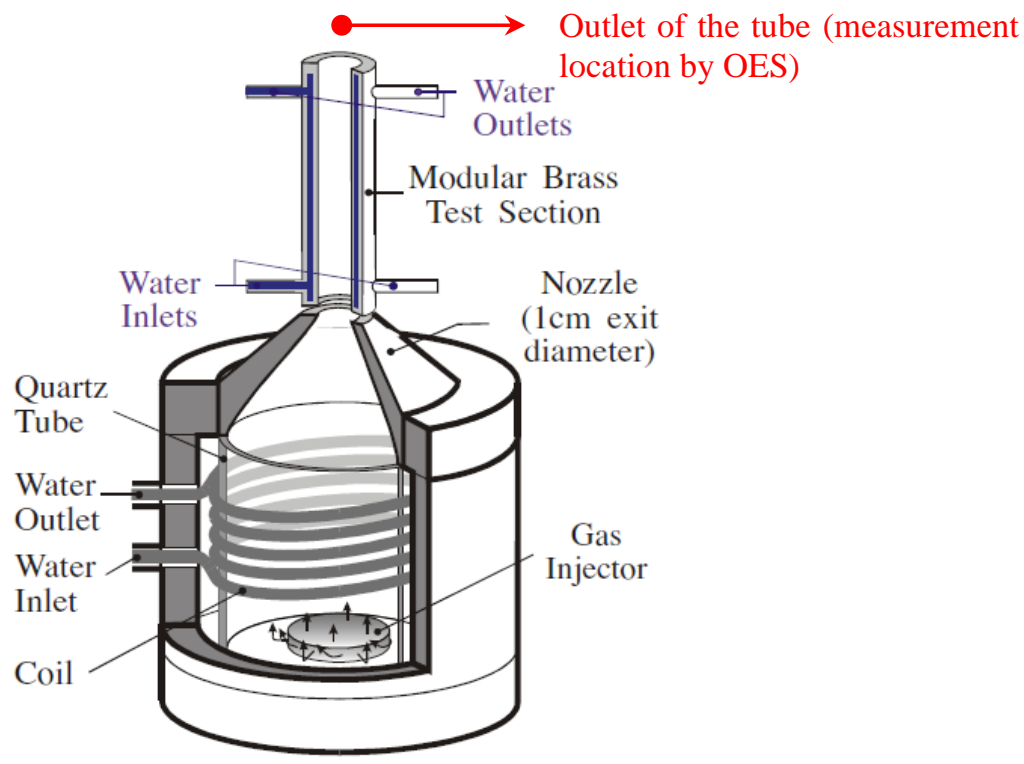

Figure 1 Schematic of the water-cooled tube (at the top) and plasma torch.

The mass flow rates at the entrance of the torch are $15.6 \mathrm{slpm}$ of air, $162 \mathrm{slpm}$ of argon and $2.3 \mathrm{slpm}$ of $\mathrm{H}_{2}$. At the inlet of the tube (outlet of the torch) the gas is in thermal and chemical equilibrium at approximately $8000 \mathrm{~K}$. It leaves the tube at approximately $2500 \mathrm{~K}$. Emission spectroscopy was performed at the tube outlet (see Figure 1) for different tube lengths: $0,10,15,40,50$ and $65 \mathrm{~cm}$. The temperatures were measured using $\mathrm{OH} \mathrm{A}-\mathrm{X}$ emission bands around 308 $\mathrm{nm}$, and the electron densities were obtained using the Stark broadening of the $\mathrm{H}_{\beta}$ line, as described in Ref. [4]. The measured and equilibrium electron densities are given in Table 1. Overpopulation factors, defined in Eq. (1) as the ratio between the density of the species $\mathrm{M}$ and its equilibrium density, are also given in this table.

$$
\rho_{M}=\frac{[M]}{[M]_{e q}}
$$

Table 1 Electron densities (measured and at equilibrium) and measured electron overpopulation factor at the exit of tubes of different lengths $z$ [4].

\begin{tabular}{ccccccc}
\hline \hline $\mathrm{z}[\mathrm{cm}]$ & 0 & 10 & 15 & 40 & 50 & 65 \\
\hline \hline $\mathrm{T}[\mathrm{K}]$ & $7980 \pm 144$ & $6687 \pm 144$ & $5863 \pm 125$ & $3450 \pm 150$ & $2800 \pm 100$ & $2510 \pm 100$ \\
\hline
\end{tabular}




\begin{tabular}{cclllll}
\hline$n_{e}^{e q}\left[\mathrm{~cm}^{-3}\right]$ & $1.5 \pm 0.3 \cdot 10^{15}$ & $2.7 \pm 0.8$ & $4.6 \pm 1.0$ & $(7.1-40)$ & $8.4 \cdot 10^{8}-1.7$ & $4.5 \cdot 10^{7}-2.0$ \\
& & $\cdot 10^{14}$ & $\cdot 10^{13}$ & $\cdot 10^{10}$ & $\cdot 10^{10}$ & $\cdot 10^{9}$ \\
$n_{e}^{e x p}\left[\mathrm{~cm}^{-3}\right]$ & $1.5 \pm 0.03 \cdot 10^{15}$ & $2.6 \pm 0.1$ & $1.4 \pm 0.06$ & $(3.4-20)$ & $5.9 \cdot 10^{10}$ & $2.3 \cdot 10^{10}$ \\
& & $\cdot 10^{14}$ & $\cdot 10^{14}$ & $\cdot 10^{11}$ & $-1.2 \cdot 10^{12}$ & $-1.1 \cdot 10^{12}$ \\
\hline$\rho_{e}-[-]$ & $0.8-1.3$ & $0.7-1.4$ & $2.4-4.1$ & $0.8-28$ & $3.5-1.4 \cdot 10^{3}$ & $12-2.4 \cdot 10^{4}$ \\
\hline \hline
\end{tabular}

The spectra also provided insights into the overpopulation factors of NO electronic states $\mathrm{A}^{2} \Sigma^{+}, \mathrm{B}^{2} \Pi, \mathrm{C}^{2} \Pi$, and $\mathrm{D}^{2} \Sigma^{+}$. The $\mathrm{NO}\left(\mathrm{C}^{2} \Pi\right)$ and $\mathrm{NO}\left(\mathrm{D}^{2} \Sigma^{+}\right)$are strongly overpopulated at 40,50 and $65 \mathrm{~cm}$ owing to chemical nonequilibrium. Table 2 contains the overpopulation factors of $\mathrm{NO}\left(\mathrm{A}^{2} \Sigma^{+}\right)$and $\mathrm{NO}\left(\mathrm{C}^{2} \Pi\right)$ obtained from the measured spectra at various lengths.

Table 2 NO(A,B,C,D) overpopulation factor at the exit of tubes of different lengths.

\begin{tabular}{ccccccc}
\hline \hline $\mathrm{z}[\mathrm{cm}]$ & 0 & 10 & 15 & 40 & 50 & 65 \\
\hline$\rho_{N O(A, B)}[-]$ & 1 & 1 & 1 & 8 & 500 & $3.8 \cdot 10^{4}$ \\
$\rho_{N O(C, D)}[-]$ & 1 & 1 & 1 & 25 & 4600 & $2.7 \cdot 10^{5}$ \\
\hline \hline
\end{tabular}

The overpopulation factors of the $\mathrm{N}_{2} \mathrm{C}^{3} \Pi_{\mathrm{u}}$ state have also been measured by Gessman et al. [4,12] and are given in Table 3 for different tube lengths. The departure from equilibrium is very significant for tube lengths longer than $40 \mathrm{~cm}$, with overpopulations of $\mathrm{N}_{2}(\mathrm{C})$ between $10^{5}$ and $10^{11}$.

Table $3 \mathrm{~N}_{2}(\mathrm{C})$ overpopulation factor at different lengths of the tube.

\begin{tabular}{ccccccc}
\hline \hline $\mathrm{z}[\mathrm{cm}]$ & 0 & 10 & 15 & 40 & 50 & 65 \\
\hline$\rho_{N_{2}(C)}[-]$ & 1 & 1 & 1 & $2.5 \cdot 10^{5}$ & $7 \cdot 10^{8}$ & $3.5 \cdot 10^{11}$ \\
\hline \hline
\end{tabular}

\section{Kinetic model and simulation parameters}

The kinetic model used is based on Park's mechanism [9]. We modified the rates of certain reactions, using the modifiedrate coefficients proposed by Gessman [12] and those of Laux et al. [13] for reactions with Argon. We do not use the corrected coefficient of Gessman for the dissociation of $\mathrm{N}_{2}$ by $\mathrm{N}_{(}\left(N_{2}+N \rightarrow N+N+N\right)$, since it was not experimentally deduced. We also used coefficients taken from Gorelov et al. [14]. The complete model (with the

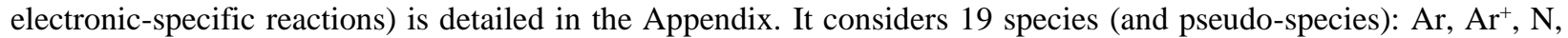
$\mathrm{N}^{+}, \mathrm{N}_{2}(\mathrm{X}, \mathrm{A}, \mathrm{B}), \mathrm{N}_{2}{ }^{+}, \mathrm{O}, \mathrm{O}^{+}, \mathrm{O}_{2}, \mathrm{O}_{2}{ }^{+}, \mathrm{NO}(\mathrm{X}, \mathrm{A}, \mathrm{B}, \mathrm{C}, \mathrm{D}), \mathrm{NO}^{+}$and electrons. This model only uses one temperature $T$ because the high pressure (atmospheric pressure) prevents any departure from thermal equilibrium (the electron translational temperature is equal to the gas temperature) [15].

The complete list of the model's reactions with their parameters is given in Table 5 of the Appendix.

\section{A. NO electronic states modeling}

1. $N O(C)$ predissociation

The NO $\mathrm{C}^{2} \Pi$ state predissociates into $\mathrm{N}$ and $\mathrm{O}$ atoms, and $\mathrm{NO}$ can also be produced in the $\mathrm{C}^{2} \Pi$ state through inverse predissociation. This phenomenon has been studied in Ref. [16]. We use the same predissociation rate as in Ref. [16], $A_{N O(C)}^{\text {pred }}=3.3 \cdot 10^{8} \mathrm{~s}^{-1}$.

2. NO electronic states radiative lifetime

The radiative lifetime of an electronic level $e$ is calculated in Eq. (2):

$$
\frac{1}{\tau_{e}}=\sum_{v^{\prime}} \sum_{v \prime \prime} \frac{A_{v^{\prime} v^{\prime \prime}} \exp \left(-\frac{E_{v^{\prime}}}{k T}\right)}{Q_{v i b}(T)}
$$

Using the Einstein coefficients $A_{v^{\prime} v}$ ' computed by Laux [16], we obtained the electronic radiative lifetimes of NO electronic levels, as displayed on Figure 2. These lifetimes correspond to the transitions from electronic states A,B,C,D,E to the ground state $X$ only: for the $\mathrm{C} \rightarrow \mathrm{A}$ transition, we used Groth et al. rate constant [17], which leads to a radiative lifetime of $\tau_{C \rightarrow A}=7.4 \cdot 10^{-8} \mathrm{~s}$. For the $D \rightarrow A$ transition, we assume that since the $\mathrm{C}$ and $\mathrm{D}$ levels are very 
close, the electron transition moment functions (ETMF) of the $C \rightarrow A$ and $D \rightarrow A$ transitions are similar and that the only difference will come from the proportionality $\alpha$ factor (given in Eq. (3)) which is 2 for D and 1 for C, leading to $\tau_{C \rightarrow A}=2 \tau_{D \rightarrow A}$ (cf. page 106 of Ref. [16]).

$$
\alpha=\frac{2-\delta_{0, \Lambda^{\prime}+\Lambda^{\prime \prime}}}{2-\delta_{0, \Lambda^{\prime}}}
$$

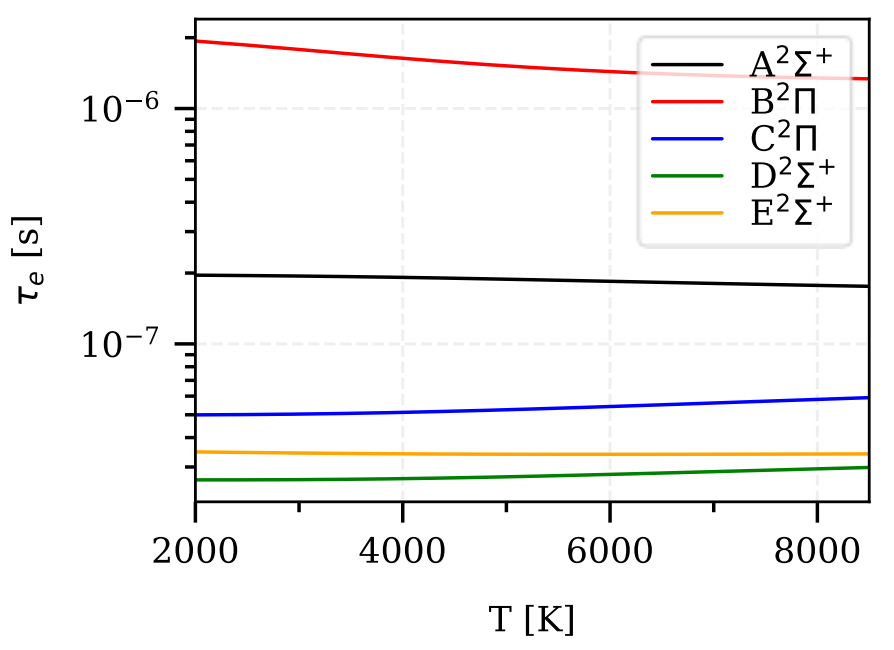

Figure 2 Radiative lifetimes of NO electronic levels as function of the temperature.

The radiative lifetimes were approximated constant over the temperature range. We obtained important differences with Johnston's radiative lifetimes [10], since he used escape factors to model the autoabsorption in the shock-tube. In this work, as a first step, we considered an optically-thin medium and thus escape factors equal to 1.

\section{Quenching of NO electronic states}

The populations of NO electronic states are strongly affected by collisional quenching. However, while most models consider collisional excitation or quenching as independent of the collider [10,14], the quenching rate coefficients depend on the collider. Raiche and Crosley [18] have seen a dependence on the collision frequency (i.e. on $\sqrt{T}$ ) for the quenching rate coefficients of $\mathrm{NO}(\mathrm{A})$ and $\mathrm{NO}(\mathrm{B})$ between 300 and $750 \mathrm{~K}$. This approximation is also used by Park in Ref. [19], where he reviews several experimental quenching data (which are also considered below). If experimental data are not available, we will use Eq. (4), even for temperatures up to $8000 \mathrm{~K}$ :

$$
k_{q}=A \cdot \sqrt{T}
$$

Quenching rate coefficients of $\mathrm{NO}(\mathrm{A})$ and $\mathrm{NO}(\mathrm{D})$ are given in Table 4 for different colliders (Ar, $\mathrm{NO}(\mathrm{X}), \mathrm{N}_{2}$ and $\mathrm{O}_{2}$ ). The adjusted $A$ coefficients are obtained by fitting experimental data from 300 to $4500 \mathrm{~K}$ for $\mathrm{NO}(\mathrm{A})$, and at 300 $\mathrm{K}$ for $\mathrm{NO}(\mathrm{D})$ (no high-temperature measurements for $\mathrm{NO}(\mathrm{D})$ ). For $\mathrm{NO}(\mathrm{A})$, the adjusted coefficients values are given below. For $\mathrm{NO}(\mathrm{D})$, we used experimental data from [20-28]. The quenching of $\mathrm{NO}(\mathrm{D})$ to $\mathrm{NO}(\mathrm{C})$ by collisions with atoms has also been studied by Laux (Eq. (5.48), page 108 of [16]) and uses the formula given in Eq. (5):

$$
k_{\text {coll }}^{D \rightarrow C}[M]\left[\mathrm{s}^{-1}\right]=0.6 \cdot 10^{10} \sqrt{\frac{300}{T}} P[\mathrm{~atm}] X_{M}
$$

with $X_{M}$ the mole fraction of the species $\mathrm{M}$ in the mixture.

Table 4 Adjusted coefficients for quenching of $\mathrm{NO}(\mathrm{A})$ and $\mathrm{NO}(\mathrm{D})$.

\begin{tabular}{ccc}
\hline \hline Quencher & \multicolumn{2}{c}{$A\left[\mathrm{~cm}^{3} / \mathrm{s}\right]$} \\
& $\mathrm{NO}(\mathrm{A})$ & $\mathrm{NO}(\mathrm{D})$ \\
\hline $\mathrm{M}($ Gorelov et al. $[14])$ & $8.63 \cdot 10^{-12}$ & $1.26 \cdot 10^{-11}$ \\
\hline $\mathrm{Ar}$ & $5.75 \cdot 10^{-15}$ & $8.72 \cdot 10^{-12}$ \\
\hline $\mathrm{NO}(\mathrm{X})$ & $1.44 \cdot 10^{-11}$ & $2.09 \cdot 10^{-11}$
\end{tabular}




\begin{tabular}{ccc}
\hline $\mathrm{N}_{2}$ & - & $8.63 \cdot 10^{-12}$ \\
\hline $\mathrm{O}_{2}$ & $8.63 \cdot 10^{-12}$ & $3.49 \cdot 10^{-11}$ \\
\hline \hline
\end{tabular}

The quenching of $\mathrm{NO}(\mathrm{A})$ by $\mathrm{N}_{2}$ can be fitted using an Arrhenius law over Thoman et al. data [29], using the rate coefficient given in Eq. (6):

$$
k_{q}^{N_{2}}=1.67 \cdot 10^{-20} \cdot T^{2.74} \cdot \exp \left(-\frac{182.8}{T}\right) \mathrm{cm}^{3} / \mathrm{s}
$$

This fit matches well the experimental data of [22,30-34] over a large temperature range (300 K $-8000 \mathrm{~K})$. The other fits suggested by $[11,35,36]$ do not agree as well over the large range of temperatures considered. The collisional quenching rate constant of $\mathrm{NO}(\mathrm{A})$ by $\mathrm{N}_{2}$ is shown in Figure 3.

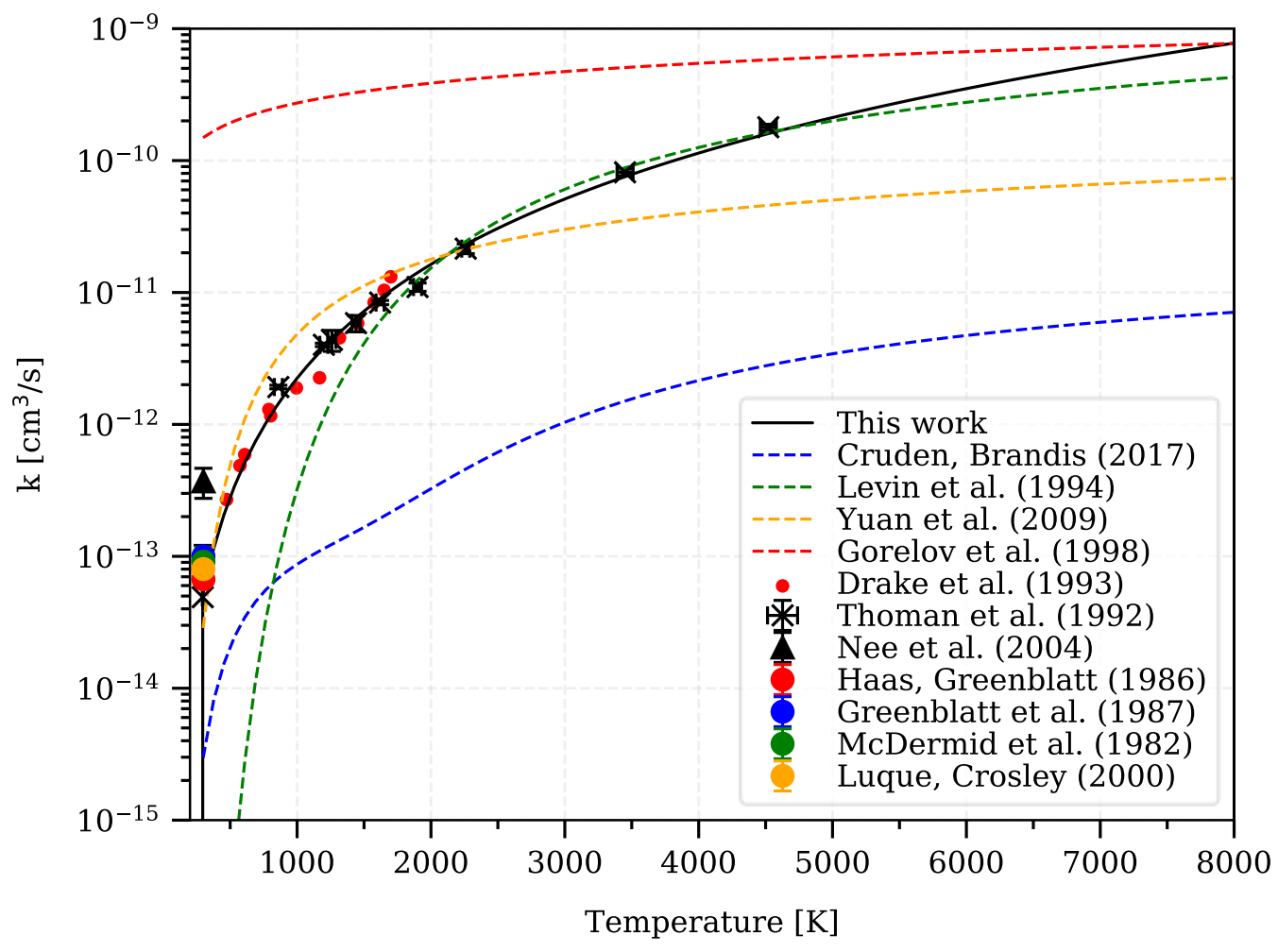

Figure 3 Rate coefficients of $\mathrm{NO}(\mathrm{A})$ quenching by $\mathrm{N}_{2}$.

The other quenching rate coefficients are displayed on Figure 4. Regarding the quenching by Argon, experimental measurements at low temperature (lower than $1500 \mathrm{~K}$ ) are scattered over a few orders of magnitudes [30,31,33,34,37,38]. We adjusted the $A$ coefficient to Gray et al. [38] data at higher temperatures (up to $2000 \mathrm{~K}$ approximately). This reaction may be important for the population of the $\mathrm{NO} \mathrm{A}^{2} \Sigma^{+}$state: indeed, the mixture is made of approximately 90\% of Argon, which thus will be the main collider. Even though the quenching efficiency of Argon is small compared to other species (e.g. $\mathrm{NO}$ or $\mathrm{O}_{2}$ ), the preponderance of Argon in the mixture may make this reaction one of the most important regarding NO(A) depletion. The rate coefficients given labelled as from Gorelov et al. [14] and as from Cruden and Brandis [11] are taken from their coefficients of quenching by an undisciminated collider M. It is assumed that this rate used in [11,14] for species present in air also applies to Argon (and to Hydrogen). The simulations performed using Cruden and Brandis [11] and Johnston's [10] models will consider Argon as a regular collider.

The quenching rate coefficients of $\mathrm{NO}(\mathrm{A})$ by $\mathrm{H}_{2}$ are shown here in prevision of future works including the trace of Hydrogen present in the mixture. Since $\mathrm{H}_{2}$ densities are very low compared to the other species, it can be safely neglected. However, the quenching rate coefficient varies of almost 3 orders of magnitude between 300 and $2000 \mathrm{~K}$. 
The rate coefficients given by $[11,14,35]$ for the quenching by NO are close to each other and in correct agreement with the experimental data from [22,25,30,37,38]. We modified the $A$ coefficient from Cruden and Brandis [11] to fit more closely the high-temperature measurements.

Regarding the quenching by $\mathrm{O}_{2}$, the coefficients given by $[11,14,35,36]$ are similar and agree well with the experimental data from $[22,23,30-34,37,39]$ for temperatures up to $2500 \mathrm{~K}$. This model uses the rate coefficient of Gorelov et al. [14] since it agrees well with the experimental data at the highest temperatures.
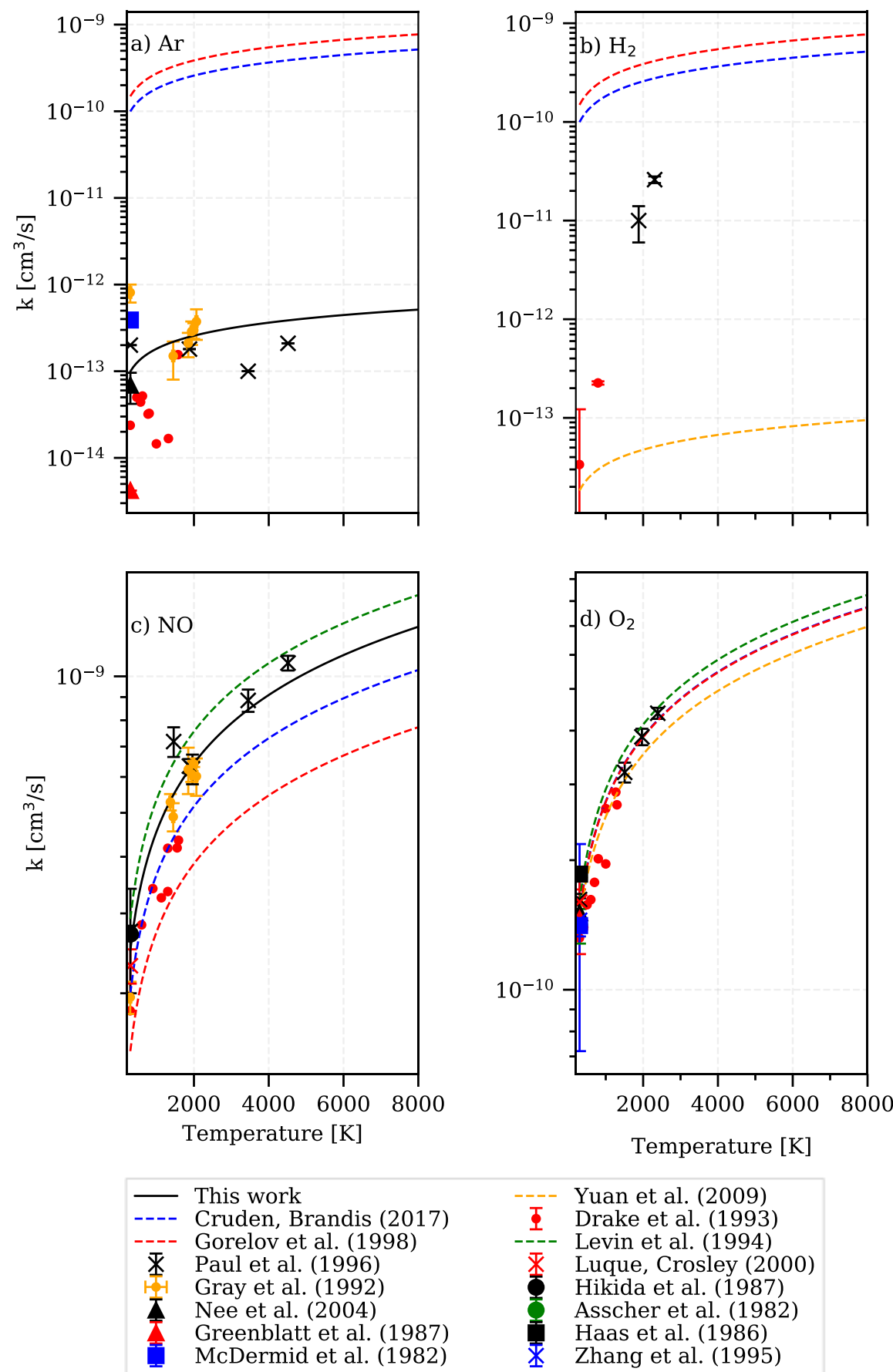

Figure 4 Rate coefficients of $\mathrm{NO}(\mathrm{A})$ quenching by (a) Argon, (b) $\mathrm{H}_{2}$, (c) $\mathrm{NO}$ and (d) $\mathrm{O}_{2}$. 
Regarding the quenching of $\mathrm{NO}(\mathrm{B})$, a few experimental data at low-temperatures $(300 \mathrm{~K})$ are available $[18,40-$ 42] for various colliders (Argon, $\mathrm{H}_{2}, \mathrm{~N}_{2}, \mathrm{O}_{2}$ and NO). These points are scattered over orders of magnitude for the same collider. We chose to use the same rate coefficients as [11], which are taken from [43] and are in good agreement with Raiche et al. [18] for the quenching by $\mathrm{O}_{2}$ up to $1000 \mathrm{~K}$.

Imajo et al. [24] measured quenching rate coefficients for $\mathrm{NO}(\mathrm{C})$ by $\mathrm{N}_{2}$ and $\mathrm{NO}$ at $300 \mathrm{~K}$ : we use $A^{N_{2}}=3.3$. $10^{-10} \mathrm{~cm}^{3} / \mathrm{s}$ and $A^{N O}=13 \cdot 10^{-10} \mathrm{~cm}^{3} / \mathrm{s}$. Although the branching ratio between $\mathrm{C}$ and $\mathrm{D}$ could explain the difference with the quenching coefficients by NO, it does not explain the differences with the quenching rate coefficients by $\mathrm{N}_{2}$. There might not be a correlation between $\mathrm{C}$ and $\mathrm{D}$ quenching rates, even though these two electronic states are close to each other. For the quenching of $\mathrm{NO}(\mathrm{C})$ by Argon and $\mathrm{O}_{2}$, we used the rate coefficients used by [11] and taken from [43].

For the quenching of the A, B, C and D states by atoms, we considered a fraction (0.6) of the kinetic rate, as was done for the quenching of D to A: $k_{q}^{\text {atom }}=0.6 \cdot 10^{-10} \cdot \sqrt{T} \mathrm{~cm}^{3} / \mathrm{s}$. In future work, we will study in more details the sensitivity of the results to these quenching rate coefficients by atomic species.

\section{4. $N_{2}(A)+N O(X) \rightarrow N_{2}(X)+N O(A)$}

The quenching of $\mathrm{N}_{2}$ (A) by $\mathrm{NO}$ can excite $\mathrm{NO}$ into the $\mathrm{A}^{2} \Sigma^{+}$state. This reaction is important for the population of $\mathrm{NO}(\mathrm{A})$. Experimental data have been obtained at low temperatures (196 or $300 \mathrm{~K}$ ) for $\mathrm{N}_{2}$ (A) quenching by NO [44]. We used the rate coefficients given by Levin et al. [35] for this reaction, considered constant over the temperature range.

However, it requires to know the population of $\mathrm{N}_{2} \mathrm{~A}^{3} \Sigma_{\mathrm{u}}{ }^{+}$electronic state. We used the reaction rate constants given by Gorelov et al. [14] for $\mathrm{N}_{2}$ electronic states X, A and B.

\section{B. Simulation parameters}

To simulate the water-cooled tube, we performed 0D simulations at constant pressure $(1 \mathrm{~atm})$, using the temperature evolution along the centerline of the tube. Figure 5 shows the temperature evolutions used in our simulations. They were obtained using 3 different assumptions on the radial temperature profile in the tube: a constant radial temperature, a parabolic radial temperature, or a radial profile obtained with CFD simulation by Candler $e t$ al. [15]. We do not consider self-absorption and do not take into account species diffusion. To compute the equilibrium populations, we used the NASA CEA code [45] at the corresponding pressure (1 atm) and temperatures. Then we can use these equilibrium populations to calculate the overpopulation factors.

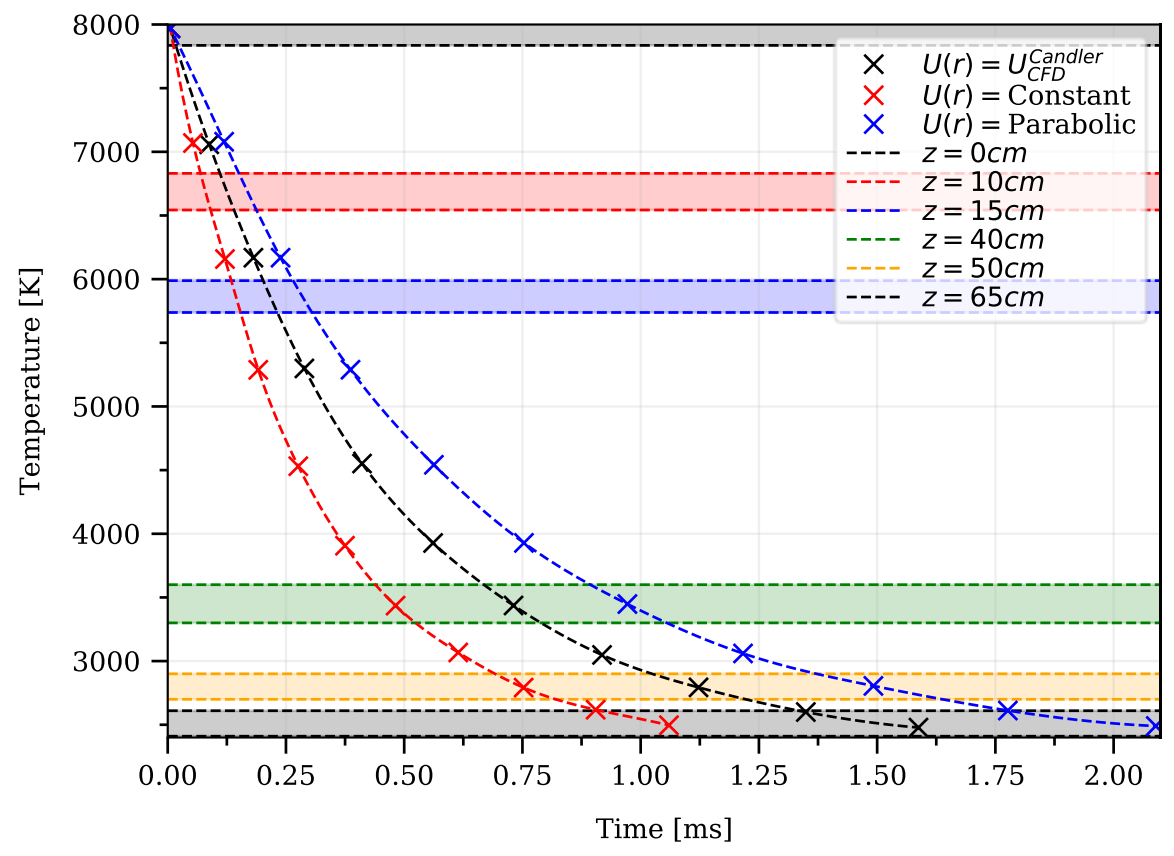

Figure 5 Temperature evolutions used for the kinetic simulations. 
The models of Johnston [10] and of Cruden and Brandis [11] have been slightly modified to take into account the high density of argon in the mixture: we added the ionization rate coefficients of Argon by electron impact from Laux et al. [13], as well as the charge exchange reaction between Argon and other ions. The rate constants of the charge exchange reaction $\mathrm{Ar}^{+}+\mathrm{M} \rightarrow \mathrm{Ar}+\mathrm{M}^{+}$are taken equal to the rate coefficient of the charge exchange reaction between Argon and $\mathrm{N}_{2}$ given in Laux et al. [13]. Moreover, when collisions with third bodies where given in both models, we took the same third-body efficiencies for Argon as for other heavy particles.

\section{Results and discussion}

Figure 6 presents the electron number densities computed and measured in the water-cooled tube. For the sake of clarity, the error bars have only been indicatd at the tube lengths where measurements have been made. The lines correspond to the average value of the simulations at a given tube length. This will be done for all the following figures presenting simulation results.

All models overpredict the electron number density, especially for longer tube lengths (above $40 \mathrm{~cm}$ ). Between 10 and $15 \mathrm{~cm}$, Johnston's and Cruden's models give electron densities between a factor 1.5 and 3 times higher than the measured electron densities, while our model agrees within a factor 2 with the measured densities. The largest discrepancies are observed at $40 \mathrm{~cm}$, where all models predict densities at least one order of magnitude too high (from 11 times too high with our model up to 30 times with Cruden's model). The discrepancies are reduced at 50 and 65 cm: Cruden's model overpredict the electron number density by a factor 15 and 20, Johnston's by a factor 4 to 7 , and our model by a factor 2 to 4.5 .

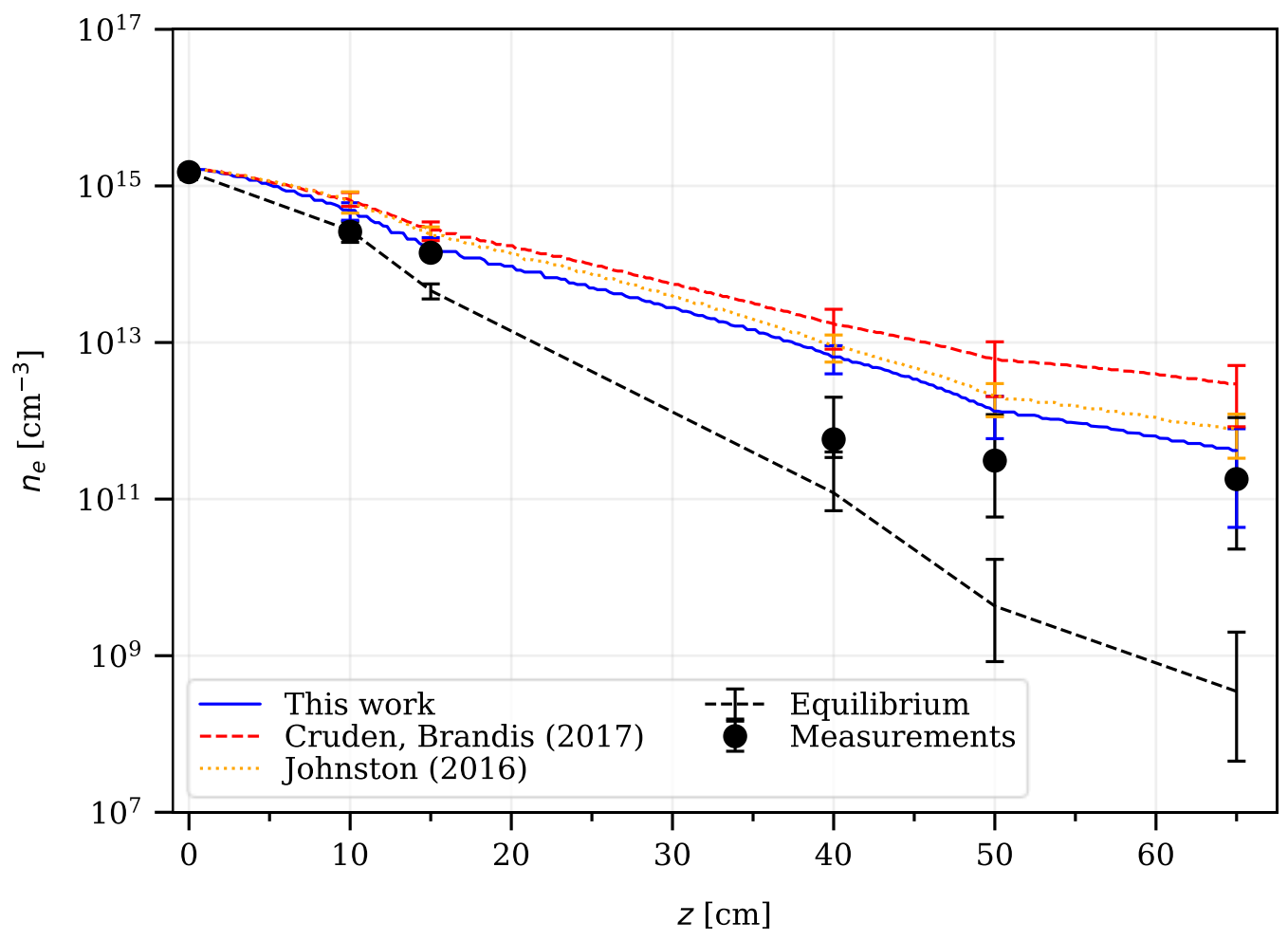

Figure 6 Electron number densities along the tube: computations (lines), measurements [4,12] (black dots) and equilibrium (black diamonds).

To gain insight on the simulation results, Figure 7 presents the net production and depletion of electrons along the tube length, for each reaction involving electrons. The dissociative recombination of $\mathrm{NO}^{+}$and $\mathrm{N}_{2}^{+}$are the main sources of electron depletion, especially for the longer tube lengths. After $30 \mathrm{~cm}$, the dissociative recombination of $\mathrm{NO}^{+}$ becomes preponderant. But is it equilibrated? 

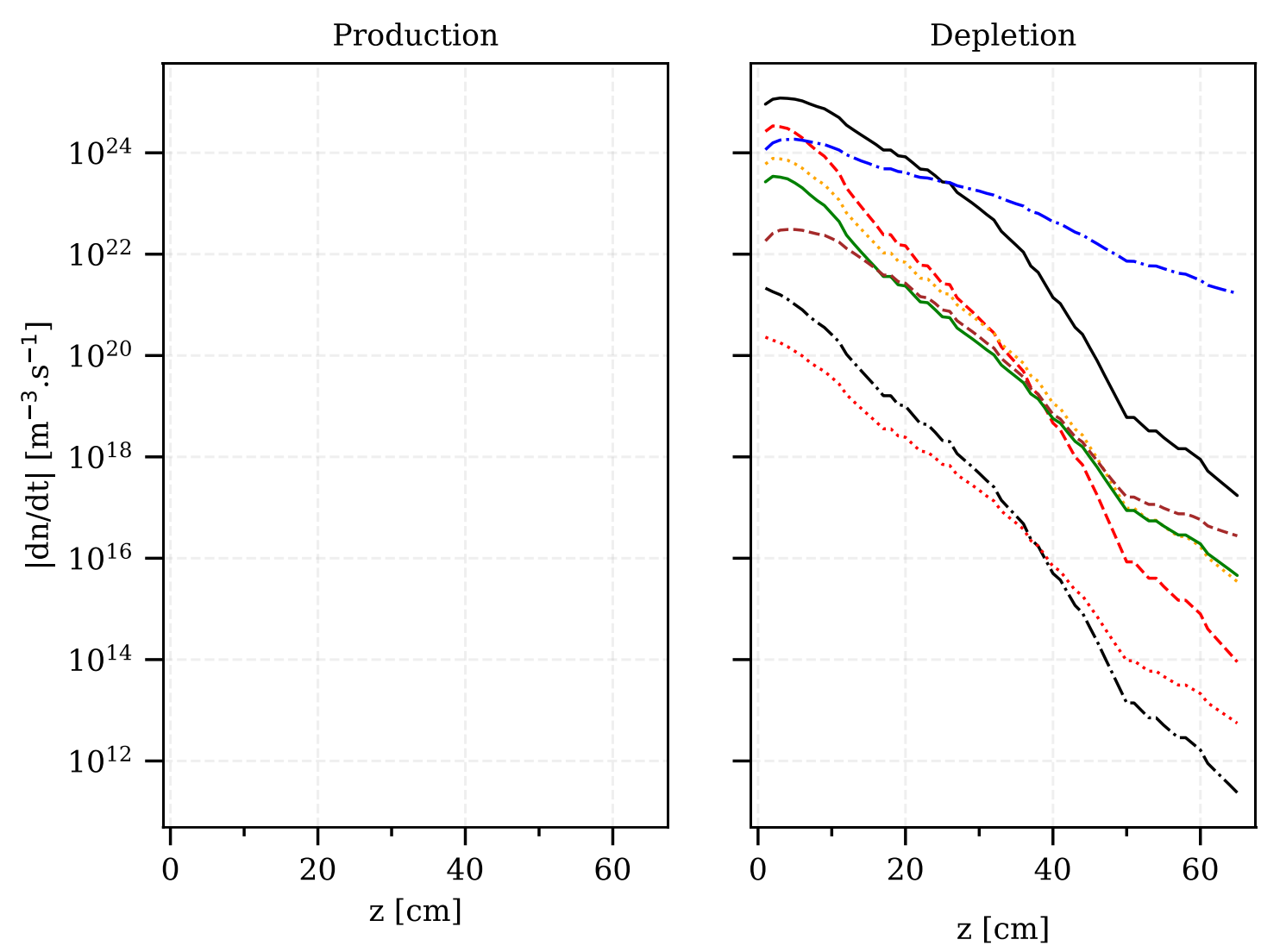

$$
\begin{array}{ll}
-\mathrm{N}+\mathrm{N} \leftrightarrow \mathrm{N}_{2}^{+}+\mathrm{e}^{-} \\
--- & \mathrm{N}+\mathrm{e}^{-} \leftrightarrow \mathrm{N}^{+}+\mathrm{e}^{-}+\mathrm{e}^{-} \\
-\cdot- & \mathrm{N}+\mathrm{O} \leftrightarrow \mathrm{NO}^{+}+\mathrm{e}^{-} \\
\cdots \cdots & \mathrm{O}+\mathrm{e}^{-} \leftrightarrow \mathrm{O}^{+}+\mathrm{e}^{-}+\mathrm{e}^{-} \\
- & \mathrm{Ar}^{+}+\mathrm{e}^{-}+\mathrm{e}^{-} \leftrightarrow \mathrm{Ar}+\mathrm{e}^{-} \\
--- & \mathrm{O}+\mathrm{O} \leftrightarrow \mathrm{O}_{2}^{+}+\mathrm{e}^{-} \\
-\cdot- & \mathrm{N}^{+}+\mathrm{e}^{-} \rightarrow \mathrm{N}+\mathrm{h} \nu \\
\cdots \cdots & \mathrm{O}^{+}+\mathrm{e}^{-} \rightarrow \mathrm{O}+\mathrm{h} \nu
\end{array}
$$

Figure 7 Net rates of main reactions involving electrons. Rates are computed with the present model and plotted along the tube centerline.

To know if a reaction is equilibrated, or if a certain direction (forward or reverse) is preponderant, one can look at the ratio of the reverse $(R)$ rate minus the forward $(F)$ rate over the sum of both rates: $(R-F) /(R+F)$. If this ratio is close to 0 , then the reaction is equilibrated. If this ratio is close to 1 , then the reverse reaction is preponderant; if the ratio is close to -1 , then the forward reaction is preponderant.

Figure 8 shows the evolution of this ratio for a selection of reactions along the tube length. Most reactions either tend to stay equilibrated along the tube axis, or tend to an extreme or another (ratios of 1 or -1 ). The dissociative recombination $\mathrm{NO}^{+}+\mathrm{e}^{-} \rightarrow \mathrm{N}+\mathrm{O}$ is equilibrated along the tube length. This can also be seen on Figure 11, with the superposition of the products of the overpopulation factors $\rho_{\mathrm{NO}^{+}} \rho_{\mathrm{e}^{-}}$and $\rho_{\mathrm{N}} \rho_{\mathrm{O}}$ along the tube length. The main reactions that deplete $\mathrm{N}$ and $\mathrm{O}$ atoms in the mixture are reactions (7-8) given below:

$$
\begin{aligned}
& \mathrm{NO}+\mathrm{N} \rightarrow \mathrm{N}+\mathrm{O}+\mathrm{N} \\
& \mathrm{NO}+\mathrm{O} \rightarrow \mathrm{N}+\mathrm{O}+\mathrm{O}
\end{aligned}
$$


These reactions are strongly non-equilibrated: their ratio $(\mathrm{R}-\mathrm{F}) /(\mathrm{R}+\mathrm{F})$ is close to 1 after $15 \mathrm{~cm}$, meaning that they produce NO by consuming atomic nitrogen and oxygen. The ions and electrons are in partial equilibrium, and some charges are consumed by the dissociative recombination reaction $\mathrm{NO}^{+}+\mathrm{e}^{-} \rightarrow \mathrm{N}+\mathrm{O}$, meaning that $\mathrm{N}$ and $\mathrm{O}$ atoms are in partial equilibrium with the electrons and $\mathrm{NO}^{+}$ions, i.e. with the charged particles in the mixture. Hence, the disappearance of charges is rate-limited by the disappearance of $\mathrm{N}$ and $\mathrm{O}$ atoms through recombination of Nitric Oxide, with the reaction $\mathrm{N}+\mathrm{O}+\mathrm{M} \rightarrow \mathrm{NO}+\mathrm{M}$. This explains the overpopulation of electrons in the water-cooled tube.

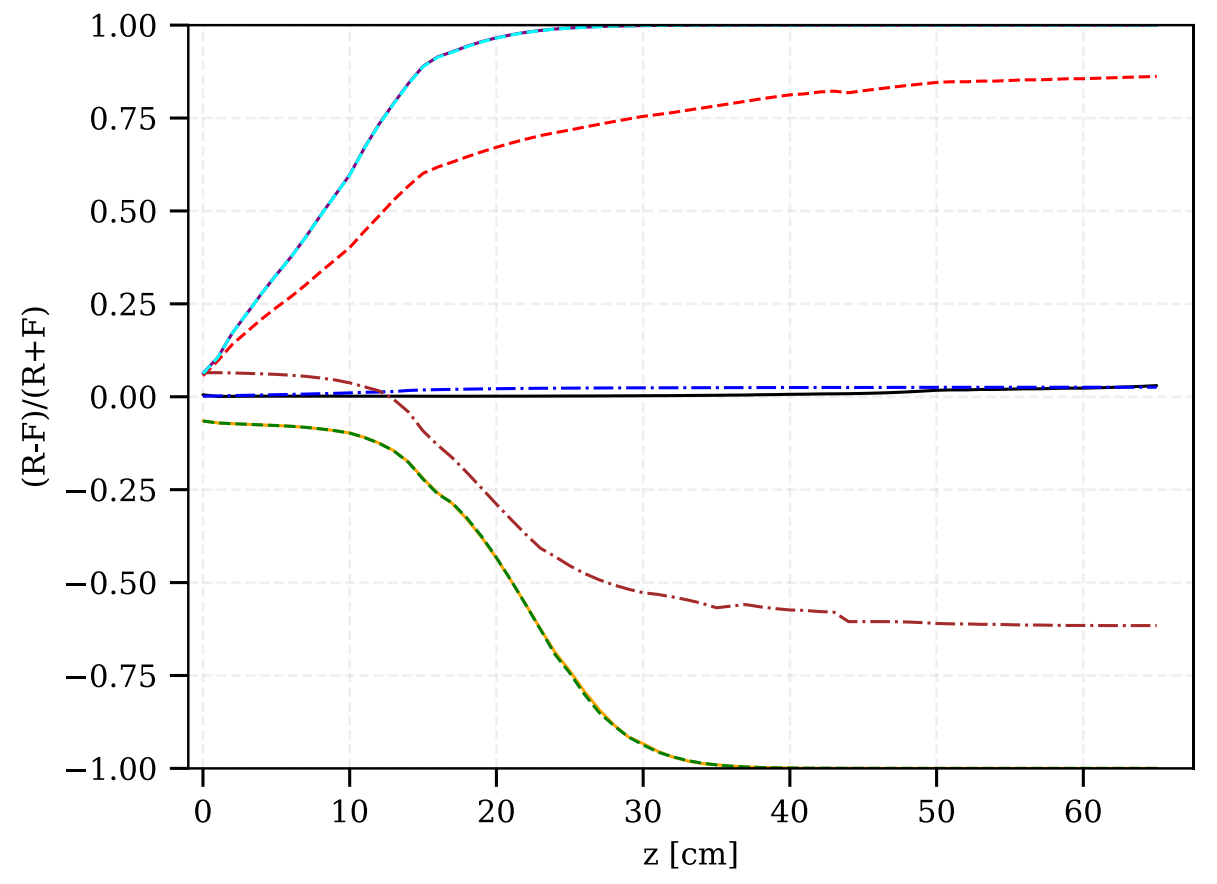

$\begin{array}{ll}-\mathrm{N}+\mathrm{O} \leftrightarrow \mathrm{NO}^{+}+\mathrm{e}^{-} \\ ----\mathrm{NO}\left(\mathrm{C}^{2} \Pi\right) \leftrightarrow \mathrm{N}+\mathrm{O} \\ -\cdot-\cdot \mathrm{NO}\left(\mathrm{D}^{2} \Sigma^{+}\right)+\mathrm{Ar} \leftrightarrow \mathrm{NO}\left(\mathrm{C}^{2} \Pi\right)+\mathrm{Ar} \\ --\mathrm{NO}\left(\mathrm{A}^{2} \Sigma^{+}\right)+\mathrm{O} \leftrightarrow \mathrm{NO}\left(\mathrm{X}^{2} \Pi\right)+\mathrm{O} \\ --- & \mathrm{NO}\left(\mathrm{A}^{2} \Sigma^{+}\right)+\mathrm{N} \leftrightarrow \mathrm{NO}\left(\mathrm{X}^{2} \Pi\right)+\mathrm{N} \\ --\cdot \cdot & \mathrm{NO}\left(\mathrm{X}^{2} \Pi\right)+\mathrm{N}_{2}\left(\mathrm{~A}^{3} \Sigma_{u}^{+}\right) \leftrightarrow \mathrm{NO}\left(\mathrm{A}^{2} \Sigma^{+}\right)+\mathrm{N}_{2}\left(\mathrm{X}^{1} \Sigma_{g}^{+}\right) \\ - & \mathrm{NO}\left(\mathrm{X}^{2} \Pi\right)+\mathrm{N} \leftrightarrow \mathrm{N}+\mathrm{O}+\mathrm{N} \\ --- & \mathrm{NO}\left(\mathrm{X}^{2} \Pi\right)+\mathrm{O} \leftrightarrow \mathrm{N}+\mathrm{O}+\mathrm{O}\end{array}$

Figure 8 Ratio of reverse $(R)$ minus forward $(F)$ rates over the sum of forward and reverse rates for a selection of reactions. A ratio of 0 means that the reaction is equilibrated.

Figure 9 compares the densities of $\mathrm{NO}\left(\mathrm{C}^{2} \Pi\right)$ computed with the different models to the measured and equilibrium densities in the water-cooled tube. All models relax towards equilibrium densities in approximately $250 \mathrm{~ms}$ for a sudden temperature drop, to be compared to the 1 to $2 \mathrm{~ms}$ of the residence time inside the water-cooled tube.

Both Cruden's and Johnston's models largely underpredict $\mathrm{NO}\left(\mathrm{C}^{2} \Pi\right)$ densities in the water-cooled tube. Due to strong quenching of $\mathrm{NO}$ excited states, $\mathrm{NO}\left(\mathrm{C}^{2} \Pi\right)$ is in partial equilibrium with $\mathrm{NO}\left(\mathrm{X}^{2} \Pi\right)$, which is largely dissociated at first, and recombines too slowly compared to the residence time inside the water-cooled tube.

Our model, on the contrary, agrees well with the measured densities: between 0 and $15 \mathrm{~cm}$, the model is within $50 \%$ discrepancies with the measurements. The largest discrepancies are at $40 \mathrm{~cm}$, as for the electron density. The model overpredicts there $\mathrm{NO}\left(\mathrm{C}^{2} \Pi\right)$ by a factor 4 . These discrepancies are reduced to $25 \%$ (resp. $\left.80 \%\right)$ at $50 \mathrm{~cm}(\mathrm{resp}$. $65 \mathrm{~cm}$ ). The model converges to the equilibrium value in approximately the same time as Johnston's and Cruden's models. 


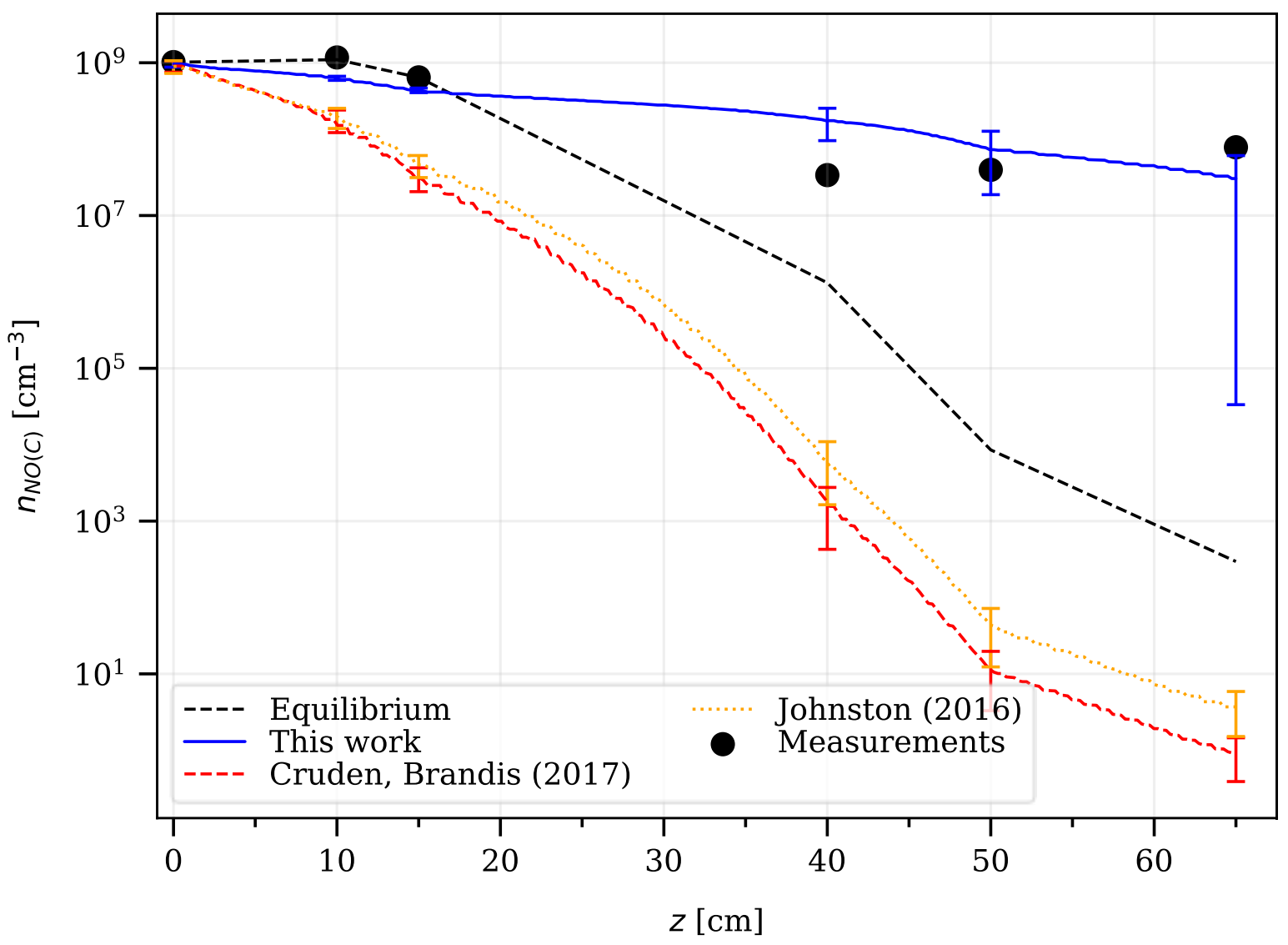

Figure 9 Densities of $\mathrm{NO}\left(\mathrm{C}^{2} \Pi\right)$ along the tube centerline: computation (lines), measurements $[4,12]$ (black dots) and equilibrium (black diamonds).

To understand the main processes responsible the NO C population, we show on Figure 10 the main reactions populating or depleting $\mathrm{NO}\left(\mathrm{C}^{2} \Pi\right)$ in the water-cooled tube. $\mathrm{NO}\left(\mathrm{C}^{2} \Pi\right)$ is only populated through inverse predissociation. It is depleted through quenching, mainly by $\mathrm{N}_{2}$ and Argon, the main species present in the mixture. The partial equilibrium between $\mathrm{NO}\left(\mathrm{C}^{2} \Pi\right)$ and $\mathrm{NO}\left(\mathrm{X}^{2} \Pi\right)$ is thus challenged by the inverse predissociation, which tries to establish partial equilibrium between $\mathrm{NO}\left(\mathrm{C}^{2} \Pi\right)$ and $\mathrm{N}$ and $\mathrm{O}$ atoms. This hypothesis of partial equilibrium between $\mathrm{NO}\left(\mathrm{C}^{2} \Pi\right)$ and $\mathrm{N}$ and $\mathrm{O}$ atoms in the tube was first formulated by Gessman et al. [4].

Also, an important process depleting $\mathrm{NO}\left(\mathrm{C}^{2} \Pi\right)$ is the excitation to $\mathrm{NO}\left(\mathrm{D}^{2} \Sigma^{+}\right)$by collisions with Argon (the main species present in the mixture). This tends to put $\mathrm{NO}\left(\mathrm{C}^{2} \Pi\right)$ and $\mathrm{NO}\left(\mathrm{D}^{2} \Sigma^{+}\right)$in partial equilibrium, which has been observed by Gessman et al. [4] in the measured spectra: both $\mathrm{NO}\left(\mathrm{C}^{2} \Pi\right)$ and $\mathrm{NO}\left(\mathrm{D}^{2} \Sigma^{+}\right)$have the same measured overpopulation factors. Our model agrees: both $\mathrm{NO}\left(\mathrm{C}^{2} \Pi\right)$ and $\mathrm{NO}\left(\mathrm{D}^{2} \Sigma^{+}\right)$have the same computed overpopulation factors, as shown in Figure 11 where the lines corresponding to these two electronic states are superposed, and the excitation reaction from $\mathrm{NO}\left(\mathrm{C}^{2} \Pi\right)$ to $\mathrm{NO}\left(\mathrm{D}^{2} \Sigma^{+}\right)$is in equilibrium, as shown on Figure 8 . 

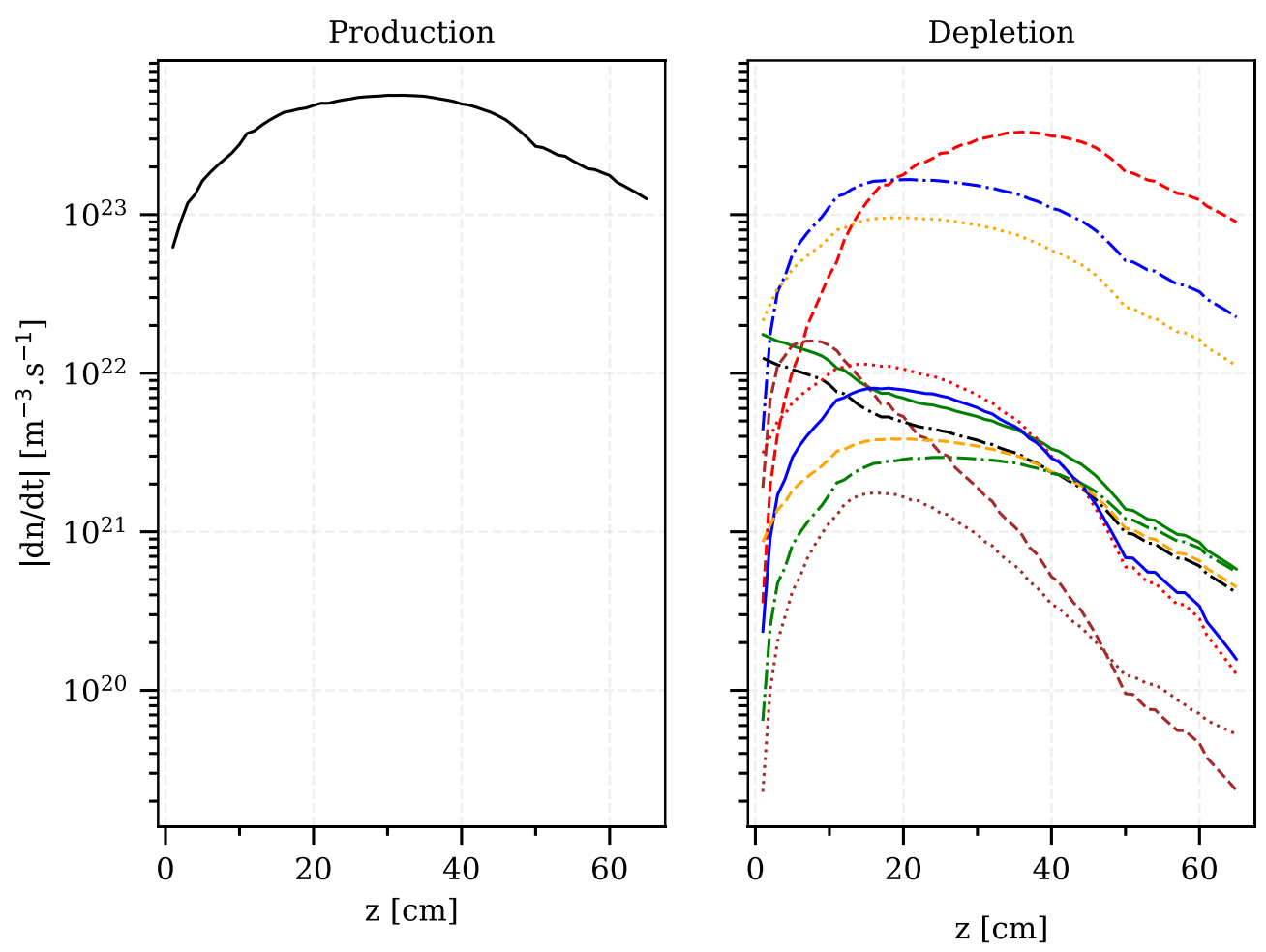

\begin{tabular}{|c|c|}
\hline 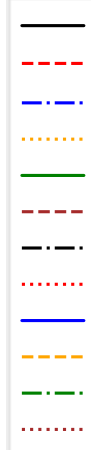 & $\begin{array}{l}\mathrm{NO}\left(\mathrm{C}^{2} \Pi\right) \leftrightarrow \mathrm{N}+\mathrm{O} \\
\mathrm{NO}\left(\mathrm{C}^{2} \Pi\right)+\mathrm{N}_{2}\left(\mathrm{X}^{1} \Sigma_{g}^{+}\right) \leftrightarrow \mathrm{NO}\left(\mathrm{X}^{2} \Pi\right)+\mathrm{N}_{2}\left(\mathrm{X}^{1} \Sigma_{g}{ }^{+}\right) \\
\mathrm{NO}\left(\mathrm{C}^{2} \Pi\right)+\mathrm{Ar} \leftrightarrow \mathrm{NO}\left(\mathrm{X}^{2} \Pi\right)+\mathrm{Ar} \\
\mathrm{NO}\left(\mathrm{D}^{2} \Sigma^{+}\right)+\mathrm{Ar} \leftrightarrow \mathrm{NO}\left(\mathrm{C}^{2} \Pi\right)+\mathrm{Ar} \\
\mathrm{NO}\left(\mathrm{C}^{2} \Pi\right) \rightarrow \mathrm{NO}\left(\mathrm{X}^{2} \Pi\right)+\mathrm{h} v \\
\mathrm{NO}\left(\mathrm{B}^{2} \Pi\right)+\mathrm{e}^{-} \leftrightarrow \mathrm{NO}\left(\mathrm{C}^{2} \Pi\right)+\mathrm{e}^{-} \\
\mathrm{NO}\left(\mathrm{C}^{2} \Pi\right) \rightarrow \mathrm{NO}\left(\mathrm{A}^{2} \Sigma^{+}\right)+\mathrm{h} \nu \\
\mathrm{NO}\left(\mathrm{D}^{2} \Sigma^{+}\right)+\mathrm{N} \leftrightarrow \mathrm{NO}^{2}\left(\mathrm{C}^{2} \Pi\right)+\mathrm{N} \\
\mathrm{NO}\left(\mathrm{C}^{2} \Pi\right)+\mathrm{N} \leftrightarrow \mathrm{NO}\left(\mathrm{X}^{2} \Pi\right)+\mathrm{N} \\
\mathrm{NO}\left(\mathrm{D}^{2} \Sigma^{+}\right)+\mathrm{O} \leftrightarrow \mathrm{NO}\left(\mathrm{C}^{2} \Pi\right)+\mathrm{O} \\
\mathrm{NO}\left(\mathrm{C}^{2} \Pi\right)+\mathrm{O} \leftrightarrow \mathrm{NO}\left(\mathrm{X}^{2} \Pi\right)+\mathrm{O} \\
\mathrm{NO}\left(\mathrm{C}^{2} \Pi\right)+\mathrm{NO}\left(\mathrm{X}^{2} \Pi\right) \leftrightarrow \mathrm{NO}\left(\mathrm{X}^{2} \Pi\right)+\mathrm{NO}\left(\mathrm{X}^{2} \Pi\right)\end{array}$ \\
\hline
\end{tabular}

\section{Figure 10 Net rates of main reactions involving $\mathrm{NO}\left(C^{2} \Pi\right)$. Rates are computed with the present model and plotted along the tube centerline.}

Figure 11 presents the computed overpopulation factors of different $\mathrm{NO}$ electronic states (X, C and D), as well as the measured overpopulation factors of $\mathrm{NO}\left(\mathrm{C}^{2} \Pi\right)$ and the products of computed overpopulation factors of $\mathrm{N}$ and $\mathrm{O}$ and of ions $\mathrm{NO}^{+}$and electrons. All computed overpopulation factors were obtained using the model described in this work. This figure allows to investigate the Gessman's hypothesis that $\mathrm{NO}\left(\mathrm{C}^{2} \Pi\right)$ is in partial equilibrium with $\mathrm{N}$ and $\mathrm{O}$ and not with $\mathrm{NO}\left(\mathrm{X}^{2} \Pi\right)$. The important discrepancies between $\mathrm{NO}\left(\mathrm{C}^{2} \Pi\right)$ and $\mathrm{NO}\left(\mathrm{X}^{2} \Pi\right)$ overpopulation factors justify the second part of the hypothesis: the $\mathrm{C}$ and $\mathrm{X}$ states are not in partial equilibrium, especially after $10 \mathrm{~cm}$. However, even if $\rho_{\mathrm{NO}(\mathrm{C})}$ and $\rho_{\mathrm{N}} \rho_{\mathrm{O}}$ follow the same trends, the existing discrepancies do not allow us to completely validate this hypothesis. It is possible to estimate $\mathrm{NO}\left(\mathrm{C}^{2} \Pi\right)$ overpopulation using $\mathrm{N}$ and $\mathrm{O}$ overpopulations, but one might overpredict $\mathrm{NO}\left(\mathrm{C}^{2} \Pi\right)$ overpopulation.

Moreover, $\rho_{\mathrm{N}} \rho_{\mathrm{O}} \approx \rho_{\mathrm{NO}^{+}} \rho_{\mathrm{e}^{-}}$in the water-cooled tube (the red and orange dotted lines are superposed). This is another way of observing that the dissociative recombination reaction $\mathrm{NO}^{+}+\mathrm{e}^{-} \rightarrow \mathrm{N}+\mathrm{O}$ is at equilibrium, as shown on Figure 8 and discussed earlier. 


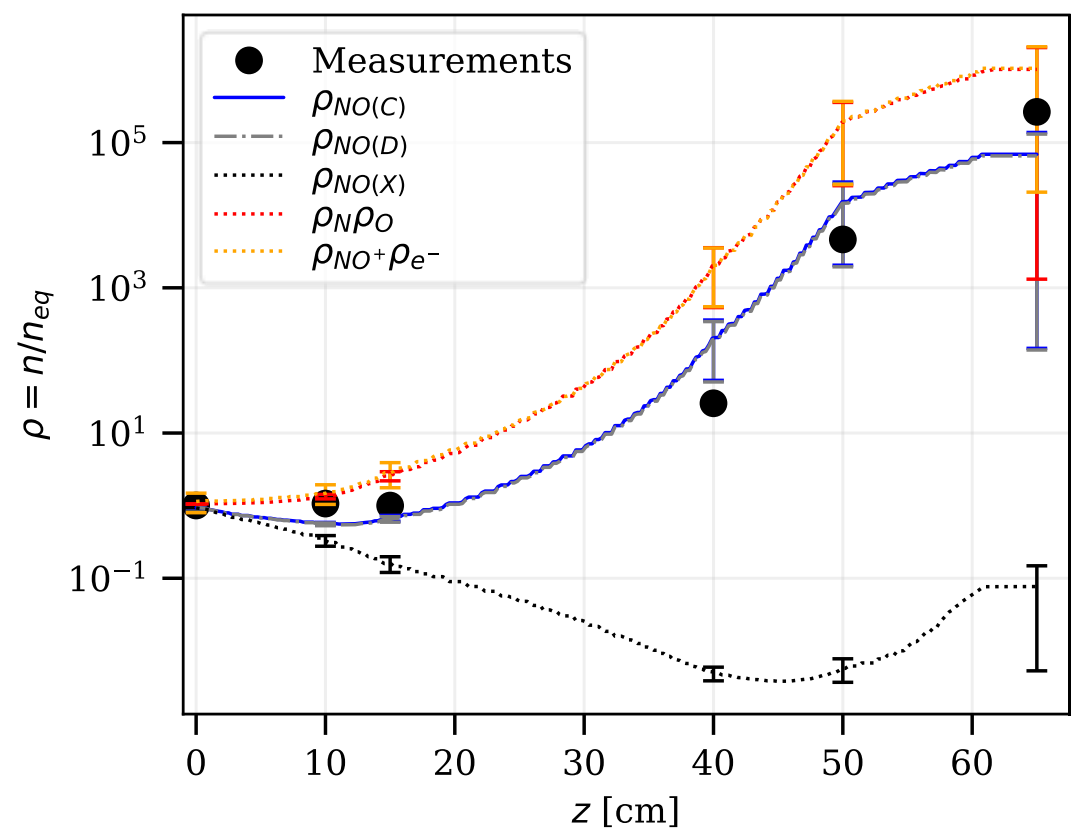

Figure $11 \mathrm{NO}\left(\mathrm{C}^{2} \Pi\right)$ overpopulation factors along the tube centerline: computation (blue line) and measurements $[4,12]$ (black circles). Computed overpopulations: $\mathrm{NO}\left(\mathrm{D}^{2} \Sigma^{+}\right)$(grey dash-dotted line), $\mathrm{NO}\left(\mathrm{X}^{2} \Pi\right)$ (black dotted line). Products of computed overpopulations: $\rho_{\mathrm{N}} \rho_{\mathrm{O}}$ (red dotted line) and $\rho_{\mathrm{NO}}+\rho_{\mathrm{e}}$ (orange dotted line). Computation are performed with the present CR model.

Figure 12 presents the computed densities of $\mathrm{NO}\left(\mathrm{A}^{2} \Sigma^{+}\right)$using the three models (Johnston's, Cruden's and ours), compared to the measured and equilibrium densities in the water-cooled tube.

The discrepancies between the predicted densities of $\mathrm{NO}\left(\mathrm{A}^{2} \Sigma^{+}\right)$and the measurements can be explained by the partial equilibrium between the A excited state and $\mathrm{NO}$ ground state due to important quenching reactions. NO, in its ground state, being largely dissociated at the entrance of the tube (due to the high temperature of approximately 8000 $\mathrm{K})$, needs longer time to recombine than the residence time inside the water-cooled tube.

Our model, on the contrary, presents the same trends for $\mathrm{NO}\left(\mathrm{A}^{2} \Sigma^{+}\right)$densities than the measured ones. The mean values given by our model agree within $75 \%$ between 0 and $15 \mathrm{~cm}$. These discrepancies are even reduced to approximately $30 \%$ at 40 and $50 \mathrm{~cm}$, and stay between a factor 2 at $65 \mathrm{~cm}$. $\mathrm{NO}\left(\mathrm{A}^{2} \Sigma^{+}\right)$density also converges to the equilibrium value outside the tube in approximately the same time as Johnston's and Cruden's models. 


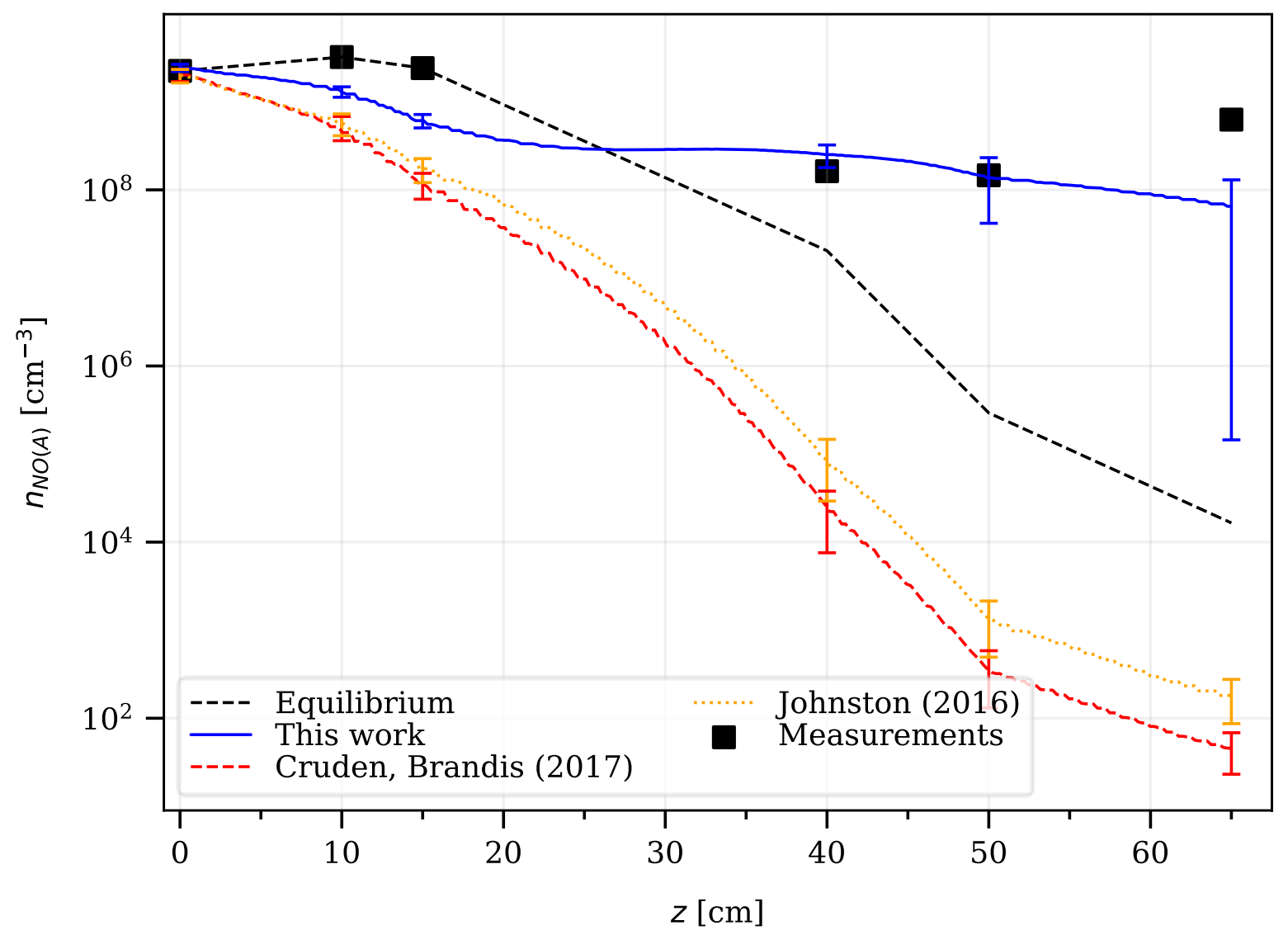

Figure 12 Densities of $\mathrm{NO}\left(\mathrm{A}^{2} \Sigma^{+}\right)$: computation (lines), measurements [4,12] (black squares) and equilibrium (black diamonds).

The main processes of $\mathrm{NO}\left(\mathrm{A}^{2} \Sigma^{+}\right)$population and depletion are presented on Figure 13. The A state of the NO molecule is mainly populated by spontaneous emission from the $\mathrm{C}$ and $\mathrm{D}$ states, and by collisions between $\mathrm{N}_{2}\left(\mathrm{~A}^{3} \Sigma_{\mathrm{u}}{ }^{+}\right)$ and $\mathrm{NO}\left(\mathrm{X}^{2} \Pi\right)$. Contrary to $\mathrm{NO}\left(\mathrm{C}^{2} \Pi\right)$, the spontaneous emission of $\mathrm{NO}\left(\mathrm{A}^{2} \Sigma^{+}\right)$is one of the main processes depleting the A state, alongside the quenching by $\mathrm{N}, \mathrm{O}$ and $\mathrm{N}_{2}$. The quenching by Argon depletes $\mathrm{NO}\left(\mathrm{A}^{2} \Sigma^{+}\right)$approximately one order of magnitude less than the quenching by $\mathrm{N}_{2}$.

These processes compete to establish partial equilibrium between $\mathrm{NO}\left(\mathrm{A}^{2} \Sigma^{+}\right)$and other species. Firstly, the quenching reactions tend to establish partial equilibrium between $\mathrm{NO}\left(\mathrm{A}^{2} \Sigma^{+}\right)$and $\mathrm{NO}\left(\mathrm{X}^{2} \Pi\right)$. Secondly, the electronic energy transfer reaction tries to establish partial equilibrium between $\mathrm{NO}\left(\mathrm{A}^{2} \Sigma^{+}\right)$and $\mathrm{N}_{2}\left(\mathrm{~A}^{3} \Sigma_{\mathrm{u}}{ }^{+}\right)$. Finally, the radiative decay of $\mathrm{NO} \mathrm{C}^{2} \Pi$ and $\mathrm{D}^{2} \Sigma^{+}$states toward $\mathrm{NO}\left(\mathrm{A}^{2} \Sigma^{+}\right)$disturbs these partial equilibrium by aligning $\mathrm{NO}\left(\mathrm{A}^{2} \Sigma^{+}\right)$ overpopulation with the overpopulation of $\mathrm{NOC}^{2} \Pi$ and $\mathrm{D}^{2} \Sigma^{+}$(which are equals, both states being in partial equilibrium as seen in Figure 8 and Figure 11). 

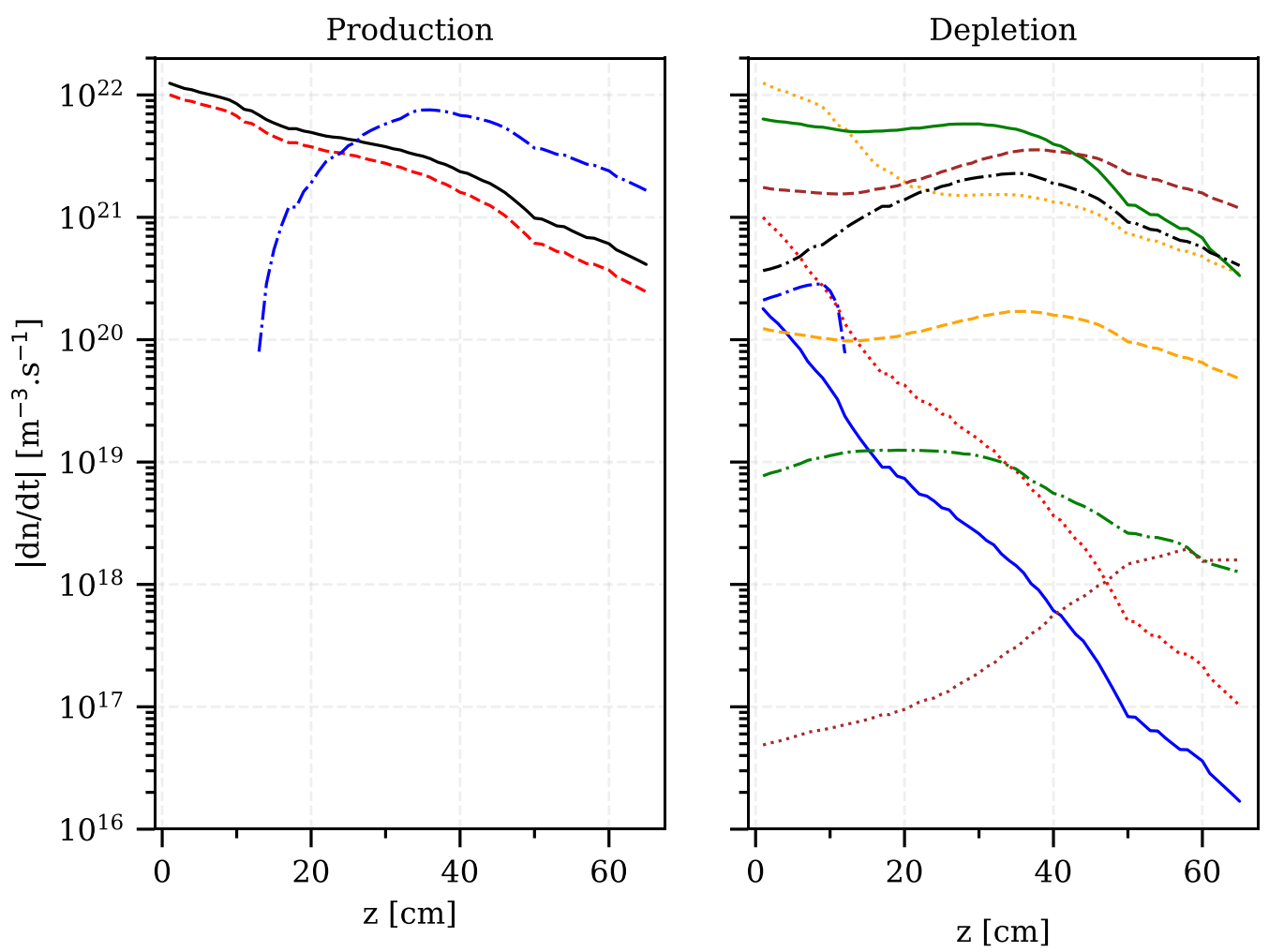

\begin{tabular}{|c|c|}
\hline- & $\mathrm{NO}\left(\mathrm{C}^{2} \Pi\right) \rightarrow \mathrm{NO}\left(\mathrm{A}^{2} \Sigma^{+}\right)+\mathrm{h} \nu$ \\
\hline ---- & $\mathrm{NO}\left(\mathrm{D}^{2} \Sigma^{+}\right) \rightarrow \mathrm{NO}\left(\mathrm{A}^{2} \Sigma^{+}\right)+\mathrm{h} \nu$ \\
\hline.-- . & $\mathrm{NO}\left(\mathrm{X}^{2} \Pi\right)+\mathrm{N}_{2}\left(\mathrm{~A}^{3} \Sigma_{u}^{+}\right) \leftrightarrow \mathrm{NO}\left(\mathrm{A}^{2} \Sigma^{+}\right)+\mathrm{N}_{2}\left(\mathrm{X}^{1} \Sigma_{q}^{+}\right)$ \\
\hline & $\mathrm{NO}\left(\mathrm{A}^{2} \Sigma^{+}\right) \rightarrow \mathrm{NO}\left(\mathrm{X}^{2} \Pi\right)+\mathrm{h} \nu$ \\
\hline & $\mathrm{NO}\left(\mathrm{A}^{2} \Sigma^{+}\right)+\mathrm{N} \leftrightarrow \mathrm{NO}\left(\mathrm{X}^{2} \Pi\right)+\mathrm{N}$ \\
\hline---- & $\mathrm{NO}\left(\mathrm{A}^{2} \Sigma^{+}\right)+\mathrm{O} \leftrightarrow \mathrm{NO}\left(\mathrm{X}^{2} \Pi\right)+\mathrm{O}$ \\
\hline & $\mathrm{NO}\left(\mathrm{A}^{2} \Sigma^{+}\right)+\mathrm{N}_{2}\left(\mathrm{X}^{1} \Sigma_{g}^{+}\right) \leftrightarrow \mathrm{NO}\left(\mathrm{X}^{2} \Pi\right)+\mathrm{N}_{2}\left(\mathrm{X}^{1} \Sigma_{g}^{+}\right)$ \\
\hline & $\begin{array}{l}\mathrm{NO}\left(\mathrm{A}^{2} \Sigma^{2}+\mathrm{e}\right. \\
\mathrm{NO}\left(\mathrm{X}^{2} \Pi\right)+\mathrm{N}_{2}\left(\mathrm{~A}^{3} \Sigma_{u}^{+}\right) \leftrightarrow \mathrm{NO}\left(\mathrm{NO}^{+}\left(\mathrm{A}^{2} \Sigma^{+}\right)+\mathrm{N}_{2}\left(\mathrm{X}^{1} \Sigma_{q}^{+}\right)\right.\end{array}$ \\
\hline & $\mathrm{NO}\left(\mathrm{X}^{2} \Pi\right)+\mathrm{e}^{-} \leftrightarrow \mathrm{NO}\left(\mathrm{A}^{2} \Sigma^{+}\right)+\mathrm{e}^{-}$ \\
\hline & $\mathrm{NO}\left(\mathrm{A}^{2} \Sigma^{+}\right)+\mathrm{Ar} \leftrightarrow \mathrm{NO}\left(\mathrm{X}^{2} \Pi\right)+\mathrm{Ar}$ \\
\hline & $\mathrm{NO}\left(\mathrm{A}^{2} \Sigma^{+}\right)+\mathrm{NO}\left(\mathrm{X}^{2} \Pi\right) \leftrightarrow \mathrm{NO}\left(\mathrm{X}^{2} \Pi\right)+\mathrm{NO}\left(\mathrm{X}^{2} \Pi\right)$ \\
\hline & $\mathrm{NO}\left(\mathrm{A}^{2} \Sigma^{+}\right)+\mathrm{O}_{2} \leftrightarrow \mathrm{NO}\left(\mathrm{X}^{2} \Pi\right)+\mathrm{O}_{2}$ \\
\hline
\end{tabular}

\section{Figure 13 Net rates of main reactions involving $\mathrm{NO}\left(\mathrm{A}^{2} \Sigma^{+}\right)$. Rates are computed with the present model and plotted along the tube centerline.}

Figure 14 shows the overpopulation factors of $\mathrm{NO}\left(\mathrm{A}^{2} \Sigma^{+}\right)$, both computed with the model presented here and measured, and the computed overpopulation factors of $\mathrm{NO}\left(\mathrm{X}^{2} \Pi\right)$ and $\mathrm{N}_{2}\left(\mathrm{~A}^{3} \Sigma_{\mathrm{u}}{ }^{+}\right)$in the water-cooled tube. Between 0 and $15 \mathrm{~cm}, \mathrm{NO}\left(\mathrm{A}^{2} \Sigma^{+}\right)$and $\mathrm{NO}\left(\mathrm{X}^{2} \Pi\right)$ overpopulation factors are equal, meaning that the excited $\mathrm{A}$ state and the ground state are in partial equilibrium. After $40 \mathrm{~cm}$, however, the excited A state is no longer in partial equilibrium with NO ground state. It is also not in partial equilibrium with $\mathrm{N}_{2}\left(\mathrm{~A}^{3} \Sigma_{\mathrm{u}}{ }^{+}\right)$, even though both overpopulation factors seem to follow the same trends. Figure 8 also shows that the electronic energy transfer reaction between $\mathrm{N}_{2}\left(\mathrm{~A}^{3} \Sigma_{\mathrm{u}}^{+}\right)$and $\mathrm{NO}\left(\mathrm{A}^{2} \Sigma^{+}\right)$is not at equilibrium, and produces far more excited $\mathrm{NO}$ than excited $\mathrm{N}_{2}$. 


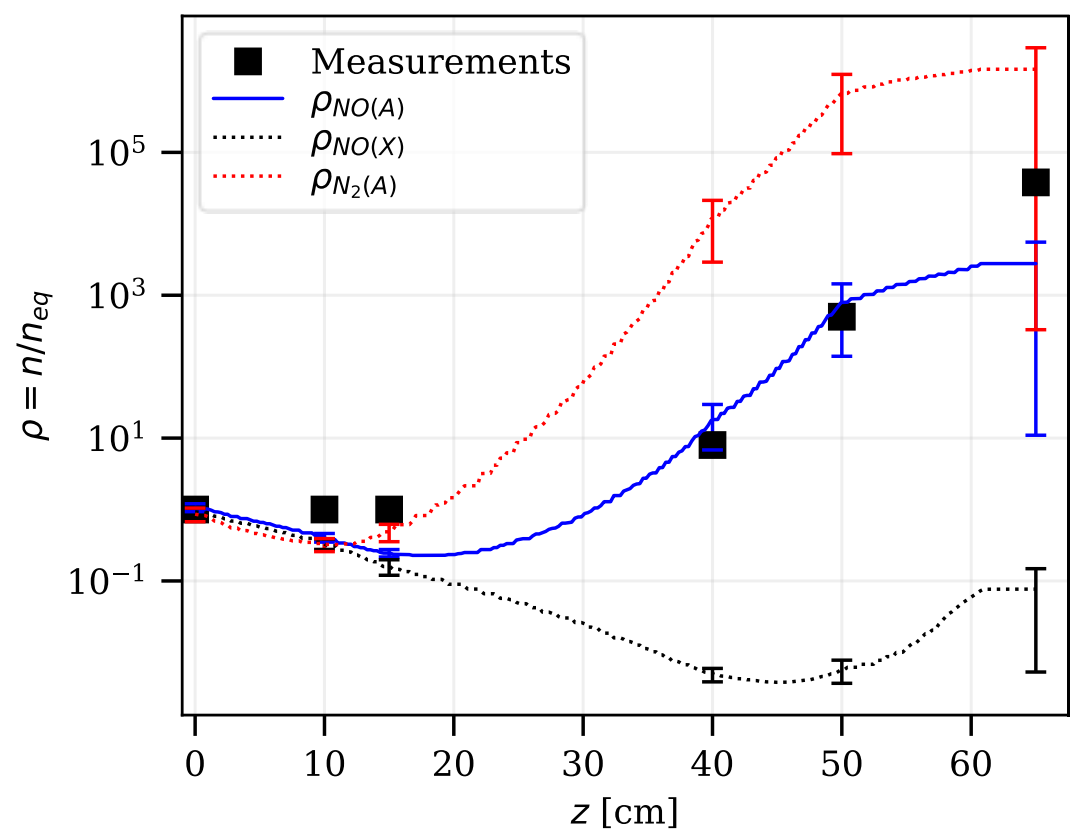

Figure $14 \mathrm{NO}\left(\mathrm{A}^{2} \Sigma^{+}\right)$overpopulation factors: computation (blue line), measurements [4,12] (black squares). Computed overpopulations factors: $\mathrm{NO}\left(\mathrm{X}^{2} \Pi\right)$ (black dotted line) and $\mathrm{N}_{2}\left(\mathrm{~A}^{3} \Sigma_{u^{+}}\right)$(red dotted line).

More details on the impact of $\mathrm{NO}\left(\mathrm{C}^{2} \Pi\right)$ predissociation and of the spontaneous emission of the $\mathrm{C}$ and $\mathrm{D}$ states toward $\mathrm{NO}\left(\mathrm{A}^{2} \Sigma^{+}\right.$) are given in Section VIII (Appendix B). We summarize on Figure 15 the results given by the model described here. This figure is made of 2 different parts: for both of them, we present the results along the tube length (using $\mathrm{z}$ ), but also as a function of the measured temperature at various lengths and as a function of the time spent in the tube. This time given is an approximation obtained using Candler's temperature profile presented in Figure 5. We reproduce the overpopulation factors presented on Figure 11 and Figure 14. We also reproduce the simulated and measured densities of $\mathrm{NO}\left(\mathrm{C}^{2} \Pi\right)$ and $\mathrm{NO}\left(\mathrm{A}^{2} \Sigma^{+}\right)$. The errorbars on the densities at the exit of the tube $(\mathrm{z}=65 \mathrm{~cm})$ go down to $3.3 \cdot 10^{4} \mathrm{~cm}^{-3}$ for $\mathrm{NO}\left(\mathrm{C}^{2} \Pi\right)$ and down to $1.5 \cdot 10^{5} \mathrm{~cm}^{-3}$ for $\mathrm{NO}\left(\mathrm{A}^{2} \Sigma^{+}\right)$.

The NO A and C excited states' overpopulation factors follow the same trend: this can be explained by the importance of $\mathrm{NO}\left(\mathrm{C}^{2} \Pi\right)$ spontaneous emission toward $\mathrm{NO}\left(\mathrm{A}^{2} \Sigma^{+}\right)$. 

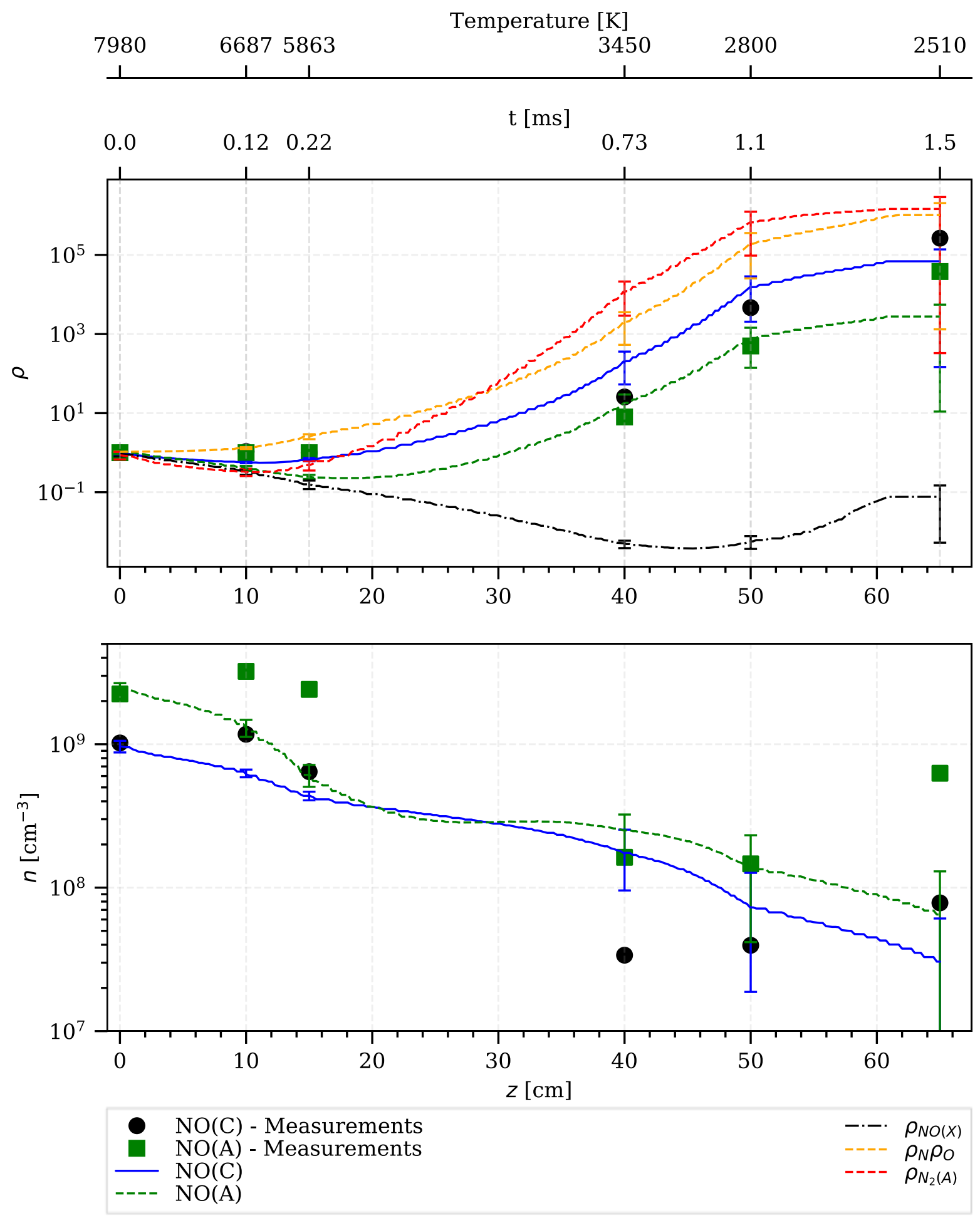

Figure 15 Summary of the results using the model presented in this work: (top) measured and computed overpopulation factors of $\mathrm{NO}\left(\mathrm{A}^{2} \Sigma^{+}\right)$(resp. green squares and green dotted line) and $\mathrm{NO}\left(\mathrm{C}^{2} \Pi\right)$ (resp. black circles and blue line) compared to computed overpopulation factors of $\mathrm{NO}\left(\mathrm{X}^{2} \Pi\right)$ (black dotted line), $\rho_{\mathrm{N} \rho \mathrm{O}}$ (orange dotted line) and $\mathrm{N}_{2}\left(\mathrm{~A}^{3} \Sigma_{\mathrm{u}^{+}}\right)$(red dotted line); and (bottom) measured and computed densities of $\mathrm{NO}\left(\mathrm{A}^{2} \Sigma^{+}\right)$and $\mathrm{NO}\left(\mathrm{C}^{2} \Pi\right)$, along the tube length and as function of time and temperature. Simulation results are obtained with the present model. 


\section{Conclusions}

We presented in this work an electronic-specific collisional-radiative model for Nitric Oxide, applied to an Air/Argon plasma produced by an ICP torch and undergoing fast recombination in a water-cooled tube. The present model, and the ones of Johnston [10] and Cruden and Brandis [11], were compared to measurements performed in the water-cooled tube by Gessman et al. [4,12].

Good agreement within a factor 4 (resp. 2) for the densities of the $\mathrm{NO} \mathrm{C}^{2} \Pi\left(\right.$ resp. $\mathrm{A}^{2} \Sigma^{+}$) state were obtained using the model presented in this work, while the models developed for shock-tube kinetics [10,11] differ by several orders of magnitude. This can be explained by $\mathrm{NO}\left(\mathrm{C}^{2} \Pi\right)$ formation via inverse predissociation and by the spontaneous emission of $\mathrm{NO} C$ and $\mathrm{D}$ states toward $\mathrm{NO}\left(\mathrm{A}^{2} \Sigma^{+}\right)$, that were not considered in Johnston's or Cruden's models. Moreover, the quenching of $\mathrm{NO}$ excited states, especially with Argon and $\mathrm{N}_{2}$, is an important factor of depletion of NO A and NO C. Collisions with Argon allow the $\mathrm{C}$ and $\mathrm{D}$ states to be in partial equilibrium. The electronic energy transfer between $\mathrm{N}_{2}\left(\mathrm{~A}^{3} \Sigma^{+}\right)$and $\mathrm{NO}\left(\mathrm{A}^{2} \Sigma^{+}\right)$is also an important process populating the A state of $\mathrm{NO}$.

Moreover, the charged species are in partial equilibrium with each other, owing to fast charge exchange and charge transfer. Furthermore, charged species are in partial equilibrium with the $\mathrm{N}$ and $\mathrm{O}$ atoms through the equilibrated dissociative recombination reaction $\mathrm{NO}^{+}+\mathrm{e}^{-} \leftrightarrow \mathrm{N}+\mathrm{O}$. Thus, the main path limiting electron recombination is the recombination of $\mathrm{N}$ and $\mathrm{O}$ atoms: $\mathrm{N}+\mathrm{O}+\mathrm{M} \rightarrow \mathrm{NO}+\mathrm{M}$. This slow process limits the depletion of charges in the mixture, and its rate is the main factor explaining the overpopulation of electrons in the water-cooled tube.

The present study gives a way to estimate the densities of the important radiative state $\mathrm{NO}\left(\mathrm{C}^{2} \Pi\right)$ from the densities of $\mathrm{N}, \mathrm{O}$ and $\mathrm{NO}(\mathrm{X})$ without running an electronic specific $\mathrm{CR}$ model: the overpopulation of $\mathrm{NO}\left(\mathrm{C}^{2} \Pi\right)$ is approximately equal to the product of $\mathrm{N}$ and $\mathrm{O}$ overpopulations $\left(\rho_{N O(C)} \approx \rho_{N} \rho_{O}\right)$ because predissociation and its inverse processes are sufficiently fast to keep $\mathrm{N}, \mathrm{O}$ and $\mathrm{NO}\left(\mathrm{C}^{2} \Pi\right)$ close to partial equilibrium. This equality holds within a factor 10 in the water-cooled tube. A more accurate prediction of $\mathrm{NO}\left(\mathrm{C}^{2} \Pi\right)$ densities requires the use of an electronic-specific model such as the one presented here.

\section{References}

[1] Johnston CO, Brandis AM. Features of Afterbody Radiative Heating for Earth Entry. J Spacecrafts and Rockets 2015;52:105-19. https://doi.org/10.2514/1.A33084.

[2] West TK, Johnston CO, Hosder S. Uncertainty and sensitivity analysis of afterbody radiative heating predictions for earth entry. J Thermophys Heat Transf 2017;31:294-306. https://doi.org/10.2514/1.T4948.

[3] Owano TG. Nonequilibrium behavior in a flowing, atmospheric pressure plasma. Ph.D. Thesis, Stanford University, 1991.

[4] Gessman RJ, Laux CO, Kruger CH. Experimental study of kinetic mechanisms of recombining atmospheric pressure air plasmas. AIAA 1997-2364, 1997. https://doi.org/10.2514/6.1997-2364.

[5] Tibère-Inglesse AC, McGuire S, Laux CO. Nonequilibrium radiation from a recombining nitrogen plasma. 2018 AIAA Aerosp Sci Meet, AIAA 2018-0241, 2018. https://doi.org/10.2514/6.2018-0241.

[6] Grimaldi C, McGuire S, Laux CO. Temperature and radiation measurements of an atmospheric pressure CO 2 plasma. AIAA Scitech 2020 Forum, Reston, Virginia, AIAA 2020-1708, 2020. https://doi.org/10.2514/6.2020-1708.

[7] Mariotto P, Tibère-Inglesse A, McGuire S, Perrin MY, Laux CO, Jacobs P, et al. Vibrational state-to-state modeling of a recombining nitrogen/argon plasma. AIAA Scitech 2019 Forum, AIAA 2019-0796, 2019. https://doi.org/10.2514/6.2019-0796.

[8] Mariotto P, Tibère-Inglesse AC, Gollan R, Jacobs P, Perrin M-Y, Laux CO. Atomic State-to-State Modeling of Ionization Nonequilibrium in a Recombining Nitrogen Plasma. AIAA Scitech 2020 Forum, Reston, Virginia, AIAA 2020-1713, 2020. https://doi.org/10.2514/6.2020-1713.

[9] Park C. Review of chemical-kinetic problems of future NASA missions. I - Earth Entries. J Thermophys Heat Transf 1993;7:385-98. https://doi.org/10.2514/3.496.

[10] Johnston CO, Brandis AM, Panesi M. Refinements to Afterbody Radiative Heating Simulations for Earth Entry. 46th AIAA Thermophys Conf, AIAA 2016-3693, 2016. https://doi.org/10.2514/6.2016-3693.

[11] Cruden BA, Brandis AM. Measurement of Radiative Non-equilibrium for Air Shocks Between 7-9 km/s. 47th AIAA Thermophys. Conf., Reston, Virginia, AIAA 2017-4535, 2017. https://doi.org/10.2514/6.2017-4535.

[12] Gessman RJ. An Experimental Investigation of the Effects of Chemical and Ionizational Equilibrium in Recombining Atmospheric Pressure Air Plasmas. Ph.D. Thesis, Stanford University, 2000.

[13] Laux CO, Gessman RJ, Kruger CH. Mechanisms of Ionizational nonequilibrium in air and nitrogen plasmas. 
26th Plasmadynamics Lasers Conf, AIAA 1995-1989, 1995. https://doi.org/10.2514/6.1995-1989.

[14] Gorelov V a., Gladyshev MK, Kireev a. Y, Yegorov I V., Plastinin Y a., Karabadzhak GF. Experimental and Numerical Study of Nonequilibrium Ultraviolet NO and N Emission in Shock Layer. J Thermophys Heat Transf 1998;12:172-9. https://doi.org/10.2514/2.6342.

[15] Candler G, Laux C, Kruger C, Gessman R, Candler G, Laux C, et al. Numerical simulation of a nonequilibrium nitrogen plasma experiment. 28th Plasmadynamics Lasers Conf, AIAA 1997-2365, 1997. https://doi.org/10.2514/6.1997-2365.

[16] Laux CO. Optical diagnostics and radiative emission of air plasmas. Ph.D. Thesis, Stanford University, 1993.

[17] Groth W, Kley D, Schurath U. Rate constant for the infrared emission of the $\mathrm{NO}(\mathrm{C} 2 \Pi \rightarrow \mathrm{A} 2 \Sigma+)$ transition. J Quant Spectrosc Radiat Transf 1971;11:1475-80. https://doi.org/10.1016/0022-4073(71)90109-9.

[18] Raiche GA, Crosley DR. Temperature dependent quenching of the A $2 \Sigma+$ and B 2 П states of NO. J Chem Phys 1990;92:5211-7. https://doi.org/10.1063/1.458604.

[19] Park C. Rate Parameters for Electonic Excitation of Diatomic Molecules II. Heavy Particle-Impact Processes. 46th AIAA Aerosp. Sci. Meet. Exhib., Reno, Nevada, AIAA 2018-1446, 2008.

[20] Nee JB, Yuan CY, Hsu J, Chen WJ, Yang JC. Collisional quenching and energy transfer of NO (D2 $\Sigma+, \mathrm{v}^{\prime}=$ 0). Chem Phys 2005;315:81-6. https://doi.org/10.1016/j.chemphys.2005.03.013.

[21] Chergui M, Le Duff Y. No D2 $\Sigma+$ fluorescence quenching by rare gas atoms and van der Waals well depths. Chem Phys 1986;105:281-9. https://doi.org/10.1016/0301-0104(86)80074-X.

[22] Luque J, Crosley DR. Radiative and predissociative rates for NO A2 $\Sigma+v^{\prime}=0-5$ and D2 $\Sigma+v^{\prime}=0-3$. J Chem Phys 2000;112:9411-6. https://doi.org/10.1063/1.481560.

[23] Asscher M, Haas Y. The quenching mechanism of electronically excited Rydberg states of nitric oxide. J Chem Phys 1982;76:2115-26. https://doi.org/10.1063/1.443306.

[24] Imajo T, Shibuya K, Obi K, Tanaka I. Energy transfer and electronic quenching of the low-lying Rydberg states of NO in NO/N2 mixtures. J Phys Chem 1986;90:6006-11. https://doi.org/10.1021/j100280a109.

[25] Hikida T, Suzuki T, Mori Y. Fluorescence lifetime studies of no a $2 \Sigma+(v=5, N=9), B 2 \Pi 32(v=8, J=8.5)$, $\mathrm{Cw} 332(v=1, \mathrm{~J}=8.5), \mathrm{D} 2 \Sigma+(v=0, \mathrm{~N}=5)$ and $\mathrm{D} 2 \Sigma+(v=1, \mathrm{~N}=9)$. Chem Phys 1987;118:437-44. https://doi.org/10.1016/0301-0104(87)85076-0.

[26] Benoist D'azy O, López-Delgado R, Tramer A. No fluorescence decay from low-lying electronic states excited into single vibronic levels with synchrotron radiation. Chem Phys 1975;9:327-38. https://doi.org/10.1016/0301-0104(75)80072-3.

[27] Hikida T, Yagi S, Mori Y. Lifetime studies of $\mathrm{NO}\left(\mathrm{A} 2 \Sigma+, v^{\prime}=4\right), \mathrm{NO}\left(\mathrm{B} 2 \Pi, v^{\prime}=9\right)$ and $\mathrm{NO}\left(\mathrm{D} 2 \Sigma+, v^{\prime}=0\right)$. Chem Phys 1980;52:399-404. https://doi.org/10.1016/0301-0104(80)85242-6.

[28] Callear AB, Pilling MJ. Fluorescence of nitric oxide. Part 6.-Predissociation and cascade quenching in NO D $2 \Sigma+(v=0)$ and NO C $2 \Pi(v=0)$, and the oscillator strengths of the $\hat{I} \mu(0,0)$ and $\delta(0,0)$ bands. Trans Faraday Soc 1970;66:1886-906. https://doi.org/10.1039/TF9706601886.

[29] Thoman JW, Gray JA, Durant JL, Paul PH. Collisional electronic quenching of NO A $2 \Sigma+$ by N2 from 300 to 4500 K. J Chem Phys 1992;97:8156-63. https://doi.org/10.1063/1.463437.

[30] Drake MC, Ratcliffe JW. High temperature quenching cross sections for nitric oxide laser-induced fluorescence measurements. J Chem Phys 1993;98:3850-65. https://doi.org/10.1063/1.465047.

[31] Nee JB, Juan CY, Hsu JY, Yang JC, Chen WJ. The electronic quenching rates of $\mathrm{NO}\left(\mathrm{A} 2 \Sigma+, \mathrm{v}^{\prime}=0-2\right)$. Chem Phys 2004;300:85-92. https://doi.org/10.1016/j.chemphys.2004.01.014.

[32] Haas Y, Greenblatt GD. A charge-transfer model for the quenching of electronically excited nitric oxide. Electron affinity of the quenchers. J Phys Chem 1986;90:513-7. https://doi.org/10.1021/j100275a032.

[33] Greenblatt GD, Ravishankara AR. Collisional quenching of $\mathrm{NO}\left(\mathrm{A}, \mathrm{v}^{\prime}=0\right)$ by various gases. Chem Phys Lett 1987;136:501-5. https://doi.org/10.1016/0009-2614(87)80506-7.

[34] McDermid IS, Laudenslager JB. Radiative lifetimes and electronic quenching rate constants for single-photonexcited rotational levels of no $\left(A 2 \Sigma+, v^{\prime}=0\right)$. J Quant Spectrosc Radiat Transf 1982;27:483-92. https://doi.org/10.1016/0022-4073(82)90100-5.

[35] Levin DA, Candler G V., Collins RJ, Erdman PW, Zipf EC, Howlett CL. Examination of ultraviolet radiation theory for bow shock rocket experiments. J Thermophys Heat Transf 1994;8. https://doi.org/10.2514/6.19922871.

[36] Yuan TH, Lai YH, Lu CJ, Chang CM. Universal calibration of quantitative OH-LIPF measurements in hydrocarbon flames at elevated pressures. Combust Explos Shock Waves 2009;45:404-12. https://doi.org/10.1007/s10573-009-0050-4.

[37] Paul PH, Gray JA, Durant JL, Thoman JW. Collisional electronic quenching rates for NO A2 $\Sigma+(v=0)$. Chem Phys Lett 1996;259:508-14. https://doi.org/10.1016/0009-2614(96)00763-4. 
[38] Gray JA, Paul PH, Durant JL. Electronic quenching rates for $\mathrm{NO}(\mathrm{A} 2 \Sigma+)$ measured in a shock tube. Chem Phys Lett 1992;190:266-70. https://doi.org/10.1016/0009-2614(92)85337-A.

[39] Zhang R, Crosley DR. Temperature dependent quenching of A $2 \Sigma+$ NO between 215 and $300 \mathrm{~K}$. J Chem Phys 1995;102:7418-24. https://doi.org/10.1063/1.469054.

[40] Black G, Sharpless RL, Slanger TG. Collisional quenching of $\mathrm{NO}(\mathrm{B} 2 \Pi r) v^{\prime}=0$ produced by the reaction of N(2D) with N2O. J Photochem 1976;5:435-45. https://doi.org/10.1016/0047-2670(76)85044-7.

[41] Campbell IM, Thrush BA. Collisional quenching of the B2П state of NO. J Quant Spectrosc Radiat Transf 1968;8:1571-5. https://doi.org/10.1016/0022-4073(68)90051-4.

[42] Melton LA, Klemperer W. Energy transfer in monochromatically excited nitric oxide: A $2 \Sigma+$ and B $2 \pi$. J Chem Phys 1973;59:1099-115. https://doi.org/10.1063/1.1680155.

[43] Cartry G, Magne L, Cernogora G. Experimental study and modelling of a low-pressure N2-O2 time afterglow. J Phys D Appl Phys 1999;32:1894-907. https://doi.org/10.1088/0022-3727/32/15/318.

[44] Young RA, John GAS. Experiments on N2(A35u+). II. Excitation of NO. J Chem Phys 1968;48:898-900. https://doi.org/10.1063/1.1668732.

[45] McBride BJ, Gordon S. Chemical Equilibrium with Applications. 1992.

[46] Thielen $\mathrm{K}$, Roth $\mathrm{P}$. Resonance absorption measurements of $\mathrm{N}$ and $\mathrm{O}$ atoms in high temperature NO dissociation and formation kinetics. Symp Combust 1985;20:685-93. https://doi.org/10.1016/S00820784(85)80558-0.

[47] Warnatz J. Rate Coefficients in the C/H/O System. Combust Chem 1984:197-360. https://doi.org/10.1007/978-1-4684-0186-8_5.

[48] Tsang W, Herron JT. Chemical Kinetic Data Base for Propellant Combustion I. Reactions Involving NO, NO 2, HNO, HNO 2 , HCN and N 2 O. J Phys Chem Ref Data 1991;20:609-63. https://doi.org/10.1063/1.555890.

\section{Appendix A}

Table 5 Model presented in this work

\begin{tabular}{|c|c|c|c|c|}
\hline Reaction & $\mathrm{A}\left[\mathrm{cm}^{3} / \mathrm{s}\right]$ & $\mathrm{n}$ & $\mathrm{E}[\mathrm{K}]$ & Ref. \\
\hline \multicolumn{5}{|l|}{$\mathrm{N}_{2}+\mathrm{M} \rightarrow \mathrm{N}+\mathrm{N}+\mathrm{M}$} \\
\hline $\mathrm{M}=\mathrm{N}, \mathrm{O}, \mathrm{N}^{+}, \mathrm{O}^{+}$ & $4.98 \mathrm{e}-2$ & -1.60 & 113200 & [9] \\
\hline$M=N_{2}$ & $4.27 \mathrm{e} 4$ & -3.33 & 113200 & [46] \\
\hline $\mathrm{M}=\mathrm{Ar}$ & $4.98 \mathrm{e}-3$ & -1.60 & 113200 & [13] \\
\hline $\mathrm{M}=\mathrm{O}_{2}, \mathrm{~N}_{2}^{+}, \mathrm{O}_{2}^{+}, \mathrm{NO}^{* *}, \mathrm{NO}^{+}$ & $1.16 \mathrm{e}-2$ & -1.60 & 113200 & [9] \\
\hline $\mathrm{M}=\mathrm{e}^{-}$ & $1.99 \mathrm{e} 1$ & -1.60 & 113200 & [9] \\
\hline \multicolumn{5}{|l|}{$\mathrm{O}_{2}+\mathrm{M} \rightarrow \mathrm{O}+\mathrm{O}+\mathrm{M}$} \\
\hline $\mathrm{M}=\mathrm{N}, \mathrm{O}, \mathrm{N}^{+}, \mathrm{O}^{+}$ & $1.66 \mathrm{e}-2$ & -1.50 & 59500 & [9] \\
\hline $\mathrm{M}=\mathrm{Ar}$ & $1.99 \mathrm{e}-10$ & 0.00 & 54280 & [47] \\
\hline $\mathrm{M}=\mathrm{N}_{2}, \mathrm{O}_{2}, \mathrm{~N}_{2}{ }^{+}, \mathrm{O}_{2}{ }^{+}, \mathrm{NO}, \mathrm{NO}^{+}$ & $3.32 \mathrm{e}-3$ & -1.50 & 59500 & [9] \\
\hline \multicolumn{5}{|l|}{$\mathrm{NO}+\mathrm{M} \rightarrow \mathrm{N}+\mathrm{O}+\mathrm{M}$} \\
\hline $\mathrm{M}=\mathrm{N}, \mathrm{O}, \mathrm{N}^{+}, \mathrm{O}^{+}$ & $1.83 \mathrm{e}-7$ & 0.00 & 75500 & [9] \\
\hline $\mathrm{M}=\mathrm{Ar}$ & $1.60 \mathrm{e}-9$ & 0.00 & 74697 & [48] \\
\hline $\mathrm{M}=\mathrm{N}_{2}, \mathrm{O}_{2}, \mathrm{~N}_{2}^{+}, \mathrm{O}_{2}^{+}, \mathrm{NO}^{+}$ & $8.30 \mathrm{e}-9$ & 0.00 & 75500 & [9] \\
\hline $\mathrm{NO}+\mathrm{O} \rightarrow \mathrm{N}+\mathrm{O}_{2}$ & $1.39 \mathrm{e}-11$ & 0.00 & 19450 & [9] \\
\hline $\mathrm{N}_{2}+\mathrm{O} \rightarrow \mathrm{NO}+\mathrm{N}$ & $1.06 \mathrm{e}-6$ & -1.00 & 38400 & [9] \\
\hline $\mathrm{N}+\mathrm{O} \rightarrow \mathrm{NO}^{+}+\mathrm{e}^{-}$ & $1.46 \mathrm{e}-15$ & 1.00 & 31900 & [9] \\
\hline $\mathrm{O}+\mathrm{O} \rightarrow \mathrm{O}_{2}^{+}+\mathrm{e}^{-}$ & $1.18 \mathrm{e}-21$ & 2.70 & 80600 & [9] \\
\hline $\mathrm{N}+\mathrm{N} \rightarrow \mathrm{N}_{2}^{+}+\mathrm{e}^{-}$ & $7.31 \mathrm{e}-17$ & 1.50 & 67500 & [9] \\
\hline $\mathrm{NO}^{+}+\mathrm{O} \rightarrow \mathrm{N}^{+}+\mathrm{O}_{2}$ & $1.66 \mathrm{e}-12$ & 0.50 & 77200 & [9] \\
\hline $\mathrm{N}^{+}+\mathrm{N}_{2} \rightarrow \mathrm{N}_{2}^{+}+\mathrm{O}_{2}$ & $1.66 \mathrm{e}-12$ & 0.50 & 12200 & [9] \\
\hline $\mathrm{O}_{2}^{+}+\mathrm{N} \rightarrow \mathrm{N}^{+}+\mathrm{O}_{2}$ & $1.44 \mathrm{e}-10$ & 0.14 & 28600 & [9] \\
\hline $\mathrm{O}^{+}+\mathrm{NO} \rightarrow \mathrm{N}^{+}+\mathrm{O}_{2}$ & $2.32 \mathrm{e}-19$ & 1.90 & 26600 & [9] \\
\hline $\mathrm{O}_{2}^{+}+\mathrm{N}_{2} \rightarrow \mathrm{N}_{2}^{+}+\mathrm{O}_{2}$ & $1.64 \mathrm{e}-11$ & 0.00 & 40700 & [9] \\
\hline $\mathrm{O}_{2}^{+}+\mathrm{O} \rightarrow \mathrm{O}^{+}+\mathrm{O}_{2}$ & $6.64 \mathrm{e}-12$ & -0.09 & 18000 & [9] \\
\hline
\end{tabular}

** If not specified otherwise in the reaction formulas, $\mathrm{NO}$ molecules in this model are considered as $\mathrm{NO}\left(\mathrm{X}^{2} \Pi\right)$. 


\begin{tabular}{|c|c|c|c|c|}
\hline $\mathrm{NO}^{+}+\mathrm{N} \rightarrow \mathrm{O}^{+}+\mathrm{N}_{2}$ & $5.65 e-11$ & -1.08 & 12800 & [9] \\
\hline $\mathrm{NO}^{+}+\mathrm{O}_{2} \rightarrow \mathrm{O}_{2}^{+}+\mathrm{NO}$ & $3.99 \mathrm{e}-11$ & 0.41 & 32600 & [9] \\
\hline $\mathrm{NO}^{+}+\mathrm{O} \rightarrow \mathrm{O}_{2}^{+}+\mathrm{N}$ & $1.20 \mathrm{e}-11$ & 0.29 & 48600 & [9] \\
\hline $\mathrm{O}^{+}+\mathrm{N}_{2} \rightarrow \mathrm{N}_{2}^{+}+\mathrm{O}$ & $1.51 \mathrm{e}-12$ & 0.36 & 22800 & [9] \\
\hline $\mathrm{NO}^{+}+\mathrm{N} \rightarrow \mathrm{N}_{2}^{+}+\mathrm{O}$ & $1.20 \mathrm{e}-10$ & 0.00 & 35500 & [9] \\
\hline $\mathrm{O}+\mathrm{e}^{-} \rightarrow \mathrm{O}^{+}+\mathrm{e}^{-}+\mathrm{e}^{-}$ & $6.48 \mathrm{e} 9$ & -3.78 & 158500 & [9] \\
\hline $\mathrm{N}+\mathrm{e}^{-} \rightarrow \mathrm{N}^{+}+\mathrm{e}^{-}+\mathrm{e}^{-}$ & $4.15 \mathrm{e} 10$ & -3.82 & 168600 & [9] \\
\hline $\mathrm{O}^{+}+\mathrm{e}^{-} \rightarrow \mathrm{O}+\mathrm{h} v$ & $1.78 \mathrm{e}-13$ & -0.52 & 0 & [9] \\
\hline $\mathrm{N}^{+}+\mathrm{e}^{-} \rightarrow \mathrm{N}+\mathrm{h} v$ & $2.52 \mathrm{e}-13$ & -0.48 & 0 & [9] \\
\hline \multicolumn{5}{|l|}{$\mathrm{Ar}^{+}+\mathrm{M} \rightarrow \mathrm{Ar}+\mathrm{M}^{+}$} \\
\hline $\mathrm{M}=\mathrm{N}_{2}, \mathrm{O}_{2}, \mathrm{NO}, \mathrm{N}, \mathrm{O}$ & $1.49 \mathrm{e}-12$ & 0.6 & 2260 & [13] \\
\hline $\mathrm{Ar}^{+}+\mathrm{e}^{-}+\mathrm{e}^{-} \rightarrow \mathrm{Ar}+\mathrm{e}^{-}$ & $2.90 \mathrm{e}-3$ & -1.0 & -47800 & [13] \\
\hline $\mathrm{H}+\mathrm{e}^{-} \rightarrow \mathrm{H}^{+}+\mathrm{e}^{-}+\mathrm{e}^{-}$ & $2.51 \mathrm{e} 7$ & -3.0 & 158000 & [13] \\
\hline $\mathrm{H}^{+}+\mathrm{N} \rightarrow \mathrm{H}+\mathrm{N}^{+}$ & $3.32 \mathrm{e}-11$ & 0.5 & 0 & [13] \\
\hline $\mathrm{H}^{+}+\mathrm{O} \rightarrow \mathrm{H}+\mathrm{O}^{+}$ & $3.32 \mathrm{e}-11$ & 0.5 & 0 & [13] \\
\hline $\mathrm{NO}(\mathrm{A})+\mathrm{Ar} \rightarrow \mathrm{NO}(\mathrm{X})+\mathrm{Ar}$ & $5.75 e-15$ & 0.5 & 0 & This work \\
\hline $\mathrm{NO}(\mathrm{A})+\mathrm{NO}(\mathrm{X}) \rightarrow \mathrm{NO}(\mathrm{X})+\mathrm{NO}(\mathrm{X})$ & $1.44 \mathrm{e}-11$ & 0.5 & 0 & This work \\
\hline $\mathrm{NO}(\mathrm{A})+\mathrm{O}_{2} \rightarrow \mathrm{NO}(\mathrm{X})+\mathrm{O}_{2}$ & $8.63 e-12$ & 0.5 & 0 & [11] \\
\hline $\mathrm{NO}(\mathrm{A})+\mathrm{H}_{2} \rightarrow \mathrm{NO}(\mathrm{X})+\mathrm{H}_{2}$ & $2.31 \mathrm{e}-13$ & 0.5 & 0 & This work \\
\hline $\mathrm{NO}(\mathrm{A})+\mathrm{N}_{2} \rightarrow \mathrm{NO}(\mathrm{X})+\mathrm{N}_{2}$ & $1.67 \mathrm{e}-20$ & 2.74 & 182.8 & This work \\
\hline $\mathrm{NO}(\mathrm{B})+\mathrm{Ar} \rightarrow \mathrm{NO}(\mathrm{X})+\mathrm{Ar}$ & $5.77 \mathrm{e}-12$ & 0.5 & 0 & [11] \\
\hline $\mathrm{NO}(\mathrm{B})+\mathrm{NO}(\mathrm{X}) \rightarrow \mathrm{NO}(\mathrm{X})+\mathrm{NO}(\mathrm{X})$ & $1.15 \mathrm{e}-11$ & 0.5 & 0 & [11] \\
\hline $\mathrm{NO}(\mathrm{B})+\mathrm{O}_{2} \rightarrow \mathrm{NO}(\mathrm{X})+\mathrm{O}_{2}$ & $8.66 \mathrm{e}-12$ & 0.5 & 0 & [11] \\
\hline $\mathrm{NO}(\mathrm{B})+\mathrm{N}_{2} \rightarrow \mathrm{NO}(\mathrm{X})+\mathrm{N}_{2}$ & $3.52 \mathrm{e}-14$ & 0.5 & 0 & [11] \\
\hline $\mathrm{NO}(\mathrm{C})+\mathrm{N}_{2} \rightarrow \mathrm{NO}(\mathrm{X})+\mathrm{N}_{2}$ & $3.30 \mathrm{e}-10$ & 0.5 & 0 & This work \\
\hline $\mathrm{NO}(\mathrm{C})+\mathrm{NO}(\mathrm{X}) \rightarrow \mathrm{NO}(\mathrm{X})+\mathrm{NO}(\mathrm{X})$ & $1.30 \mathrm{e}-9$ & 0.5 & 0 & This work \\
\hline $\mathrm{NO}(\mathrm{C})+\mathrm{O}_{2} \rightarrow \mathrm{NO}(\mathrm{X})+\mathrm{O}_{2}$ & $8.66 \mathrm{e}-13$ & 0.5 & 0 & [11] \\
\hline $\mathrm{NO}(\mathrm{C})+\mathrm{Ar} \rightarrow \mathrm{NO}(\mathrm{X})+\mathrm{Ar}$ & $5.77 \mathrm{e}-12$ & 0.5 & 0 & [11] \\
\hline $\mathrm{NO}(\mathrm{D})+\mathrm{N}_{2} \rightarrow \mathrm{NO}(\mathrm{X})+\mathrm{N}_{2}$ & $8.63 \mathrm{e}-12$ & 0.5 & 0 & This work \\
\hline $\mathrm{NO}(\mathrm{D})+\mathrm{NO}(\mathrm{X}) \rightarrow \mathrm{NO}(\mathrm{X})+\mathrm{NO}(\mathrm{X})$ & $2.09 \mathrm{e}-11$ & 0.5 & 0 & This work \\
\hline $\mathrm{NO}(\mathrm{D})+\mathrm{O}_{2} \rightarrow \mathrm{NO}(\mathrm{X})+\mathrm{O}_{2}$ & $3.49 \mathrm{e}-11$ & 0.5 & 0 & This work \\
\hline $\mathrm{NO}(\mathrm{D})+\mathrm{Ar} \rightarrow \mathrm{NO}(\mathrm{X})+\mathrm{Ar}$ & $8.72 \mathrm{e}-12$ & 0.5 & 0 & This work \\
\hline \multicolumn{5}{|l|}{$\mathrm{NO}(\mathrm{D})+\mathrm{M} \rightarrow \mathrm{NO}(\mathrm{C})+\mathrm{M}$} \\
\hline $\mathrm{M}=\mathrm{N}, \mathrm{O}, \mathrm{Ar}$ & $1.80 \mathrm{e}-10$ & 0.5 & 0 & [16] \\
\hline $\begin{array}{c}\mathrm{NO}(\mathrm{A}, \mathrm{B}, \mathrm{C}, \mathrm{D})+\mathrm{M} \rightarrow \mathrm{NO}(\mathrm{X})+\mathrm{M} \\
\mathrm{M}=\mathrm{N}, \mathrm{O}\end{array}$ & $1.80 \mathrm{e}-10$ & 0.5 & 0 & This work \\
\hline $\mathrm{NO}(\mathrm{X})+\mathrm{e}^{-} \rightarrow \mathrm{NO}(\mathrm{A})+\mathrm{e}^{-}$ & $1.20 \mathrm{e}-10$ & 0.0 & 63500 & [14] \\
\hline $\mathrm{NO}(\mathrm{X})+\mathrm{e}^{-} \rightarrow \mathrm{NO}(\mathrm{B})+\mathrm{e}^{-}$ & $1.01 \mathrm{e}-10$ & 0.0 & 65700 & [14] \\
\hline $\mathrm{NO}(\mathrm{X})+\mathrm{e}^{-} \rightarrow \mathrm{NO}(\mathrm{C})+\mathrm{e}^{-}$ & $1.39 \mathrm{e}-10$ & 0.0 & 74300 & [14] \\
\hline $\mathrm{NO}(\mathrm{X})+\mathrm{e}^{-} \rightarrow \mathrm{NO}(\mathrm{D})+\mathrm{e}^{-}$ & $1.39 \mathrm{e}-10$ & 0.0 & 74300 & [14] \\
\hline $\mathrm{NO}(\mathrm{A})+\mathrm{e}^{-} \rightarrow \mathrm{NO}(\mathrm{B})+\mathrm{e}^{-}$ & $1.99 \mathrm{e}-9$ & 0.0 & 0 & [14] \\
\hline $\mathrm{NO}(\mathrm{B})+\mathrm{e}^{-} \rightarrow \mathrm{NO}(\mathrm{C})+\mathrm{e}^{-}$ & $6.81 \mathrm{e}-9$ & 0.0 & 0 & [14] \\
\hline $\mathrm{NO}(\mathrm{C}) \rightarrow \mathrm{N}+\mathrm{O}$ & $3.3 \mathrm{e} 8^{\dagger \dagger}$ & - & - & {$[16]$} \\
\hline $\mathrm{NO}(\mathrm{A}) \rightarrow \mathrm{NO}(\mathrm{X})+\mathrm{h} v$ & $1.883 \mathrm{e}-7 \pm$ & - & - & [16] \\
\hline $\mathrm{NO}(\mathrm{B}) \rightarrow \mathrm{NO}(\mathrm{X})+\mathrm{h} v$ & $1.518 \mathrm{e}-6$ & - & - & [16] \\
\hline $\mathrm{NO}(\mathrm{C}) \rightarrow \mathrm{NO}(\mathrm{X})+\mathrm{h} v$ & $5.251 \mathrm{e}-8$ & - & - & [16] \\
\hline $\mathrm{NO}(\mathrm{C}) \rightarrow \mathrm{NO}(\mathrm{A})+\mathrm{h} v$ & $7.4 \mathrm{e}-8$ & - & - & [17] \\
\hline $\mathrm{NO}(\mathrm{D}) \rightarrow \mathrm{NO}(\mathrm{X})+\mathrm{h} v$ & $2.725 \mathrm{e}-8$ & - & - & [16] \\
\hline $\mathrm{NO}(\mathrm{D}) \rightarrow \mathrm{NO}(\mathrm{A})+\mathrm{h} v$ & $3.7 \mathrm{e}-8$ & - & - & This work \\
\hline $\mathrm{NO}\left(\mathrm{B}^{\prime}\right) \rightarrow \mathrm{NO}(\mathrm{X})+\mathrm{h} v$ & $1.669 \mathrm{e}-7$ & - & - & [16] \\
\hline
\end{tabular}

${ }^{\dagger} \mathrm{In} \mathrm{s}^{-1}$. The rate constant of $\mathrm{NO}(\mathrm{C})$ predissociation depends heavily on the vibrational and rotational level $(\mathrm{v}, \mathrm{J})$ : this A coefficient is between $3.3 \mathrm{e} 7$ and $2.0 \mathrm{e}^{-10 \mathrm{~s}^{-1}}$. Here we considered the value for the rovibrational states $\mathrm{v}=0, \mathrm{~J}>4.5$ since approximately $96 \%$ of $\mathrm{NO}(\mathrm{C}, \mathrm{v}=0)$ levels have rotational numbers larger than 4.5 at $2300 \mathrm{~K}$ (wich is approximately the temperature at the exit of the $65-\mathrm{cm}$ tube).

$\$$ Lifetimes in $\mathrm{s}$. 


\begin{tabular}{ccccc}
$\mathrm{NO}(\mathrm{E}) \rightarrow \mathrm{NO}(\mathrm{X})+\mathrm{h} \nu$ & $3.398 \mathrm{e}-8$ & - & - & {$[16]$} \\
$\mathrm{N}_{2}(\mathrm{X})+\mathrm{N}_{2}(\mathrm{X}) \rightarrow \mathrm{N}_{2}(\mathrm{~A})+\mathrm{N}_{2}(\mathrm{X})$ & $1.83 \mathrm{e}-12$ & -0.5 & 71600 & {$[14]$} \\
$\mathrm{N}_{2}(\mathrm{X})+\mathrm{N} \rightarrow \mathrm{N}_{2}(\mathrm{~A})+\mathrm{N}$ & $1.99 \mathrm{e}-7$ & -1.5 & 71600 & {$[14]$} \\
$\mathrm{N}_{2}(\mathrm{X})+\mathrm{O} \rightarrow \mathrm{N}_{2}(\mathrm{~A})+\mathrm{O}$ & $1.20 \mathrm{e}-7$ & -1.5 & 71600 & {$[14]$} \\
$\mathrm{N}_{2}(\mathrm{X})+\mathrm{O}_{2} \rightarrow \mathrm{N}_{2}(\mathrm{~A})+\mathrm{O}_{2}$ & $9.96 \mathrm{e}-9$ & -1.5 & 71600 & {$[14]$} \\
$\mathrm{N}+\mathrm{N}+\mathrm{N}_{2}(\mathrm{X}) \rightarrow \mathrm{N}_{2}(\mathrm{~A})+\mathrm{N}_{2}(\mathrm{X})$ & $2.21 \mathrm{e}-31^{\S \S}$ & -0.8 & 0 & {$[14]$} \\
$\mathrm{N}+\mathrm{N} \rightarrow \mathrm{N}_{2}(\mathrm{~A})$ & $8.14 \mathrm{e}-17$ & -0.35 & 0 & {$[14]$} \\
$\mathrm{N}_{2}(\mathrm{~A})+\mathrm{N}_{2}(\mathrm{~A}) \rightarrow \mathrm{N}_{2}(\mathrm{~B})+\mathrm{N}_{2}(\mathrm{X})$ & $1.23 \mathrm{e}-9$ & 0 & 0 & {$[14]$} \\
$\mathrm{N}_{2}(\mathrm{X})+\mathrm{e}^{-} \rightarrow \mathrm{N}_{2}(\mathrm{~A})+\mathrm{e}^{-}$ & $1.02 \mathrm{e}-8$ & 0 & 71600 & {$[14]$} \\
$\mathrm{N}_{2}(\mathrm{~A})+\mathrm{e}^{-} \rightarrow \mathrm{N}_{2}(\mathrm{~B})+\mathrm{e}^{-}$ & $3.01 \mathrm{e}-10$ & 0 & 0 & {$[14]$} \\
$\mathrm{NO}(\mathrm{X})+\mathrm{N}_{2}(\mathrm{~A}) \rightarrow \mathrm{NO}(\mathrm{A})+\mathrm{N}_{2}(\mathrm{X})$ & $6.64 \mathrm{e}-11$ & 0 & 0 & {$[35]$} \\
\hline
\end{tabular}

\section{Appendix B}

To observe the impact of $\mathrm{NO}\left(\mathrm{C}^{2} \Pi\right)$ predissociation and of the spontaneous emission of the $\mathrm{C}$ and $\mathrm{D}$ states toward the A state, these reactions have been added to Johnston's and Cruden's models. The densities of the C and A states are shown respectively on Figure 16 and Figure 17. While it does not change fundamentaly the behavior of Johnston's model, Cruden's model gives completely different results and is far closer to the measurements than before. The rate coefficients and radiative lifetime used are sufficient to compensate the quenching of the $\mathrm{A}$ and $\mathrm{C}$ states and to prevent these two excited states to be in partial equilibrium with $\mathrm{NO}$ ground state.

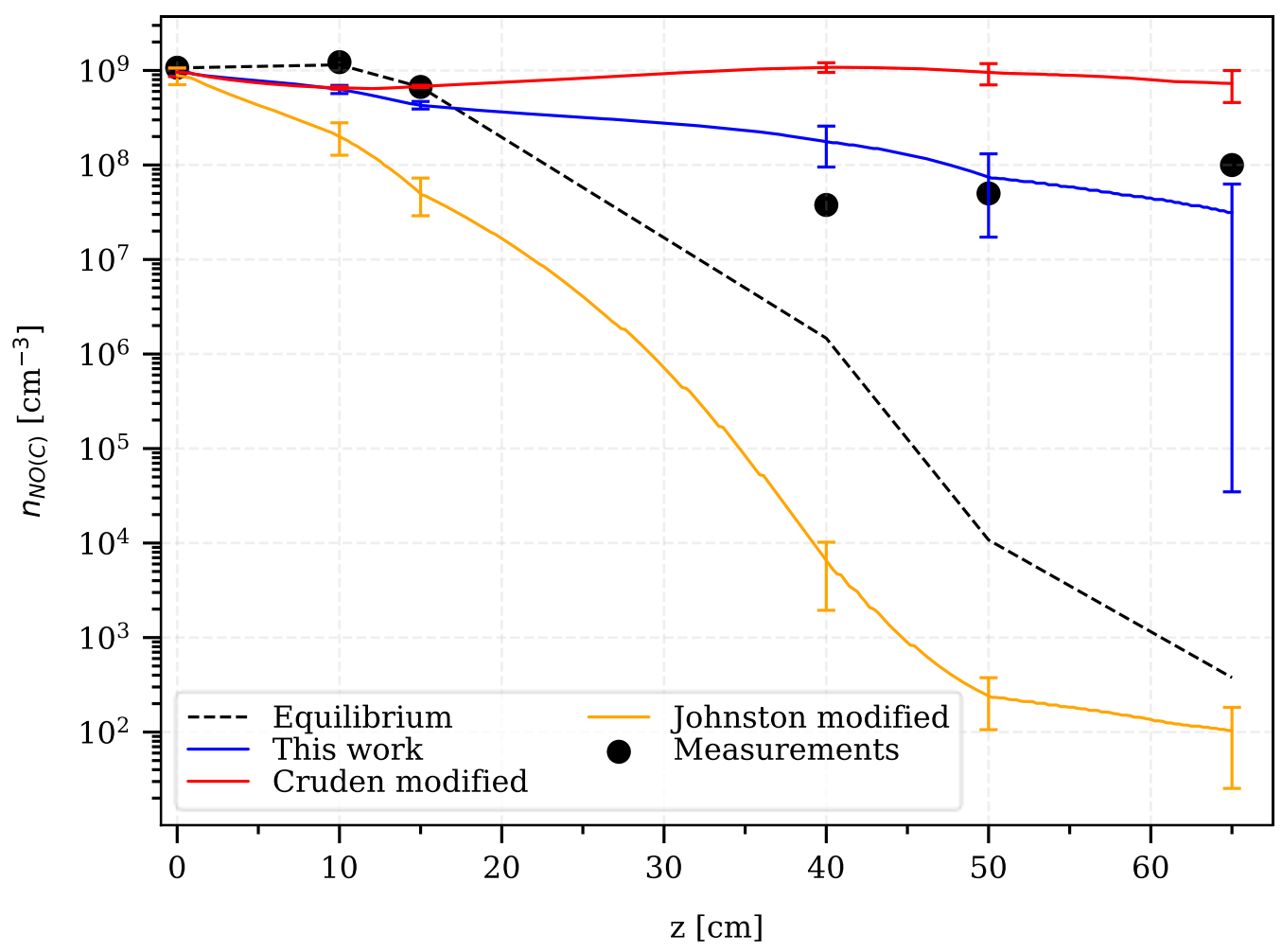

Figure 16 Densities of $\mathrm{NO}\left(\mathrm{C}^{2} \Pi\right)$ computed (lines) with updated Johnston's and Cruden's models compared to measured (black dots) and equilibrium (black diamonds) densities.

$\S \S$ The unit for $\mathrm{A}$ is $\mathrm{cm}^{6} / \mathrm{s}$. 


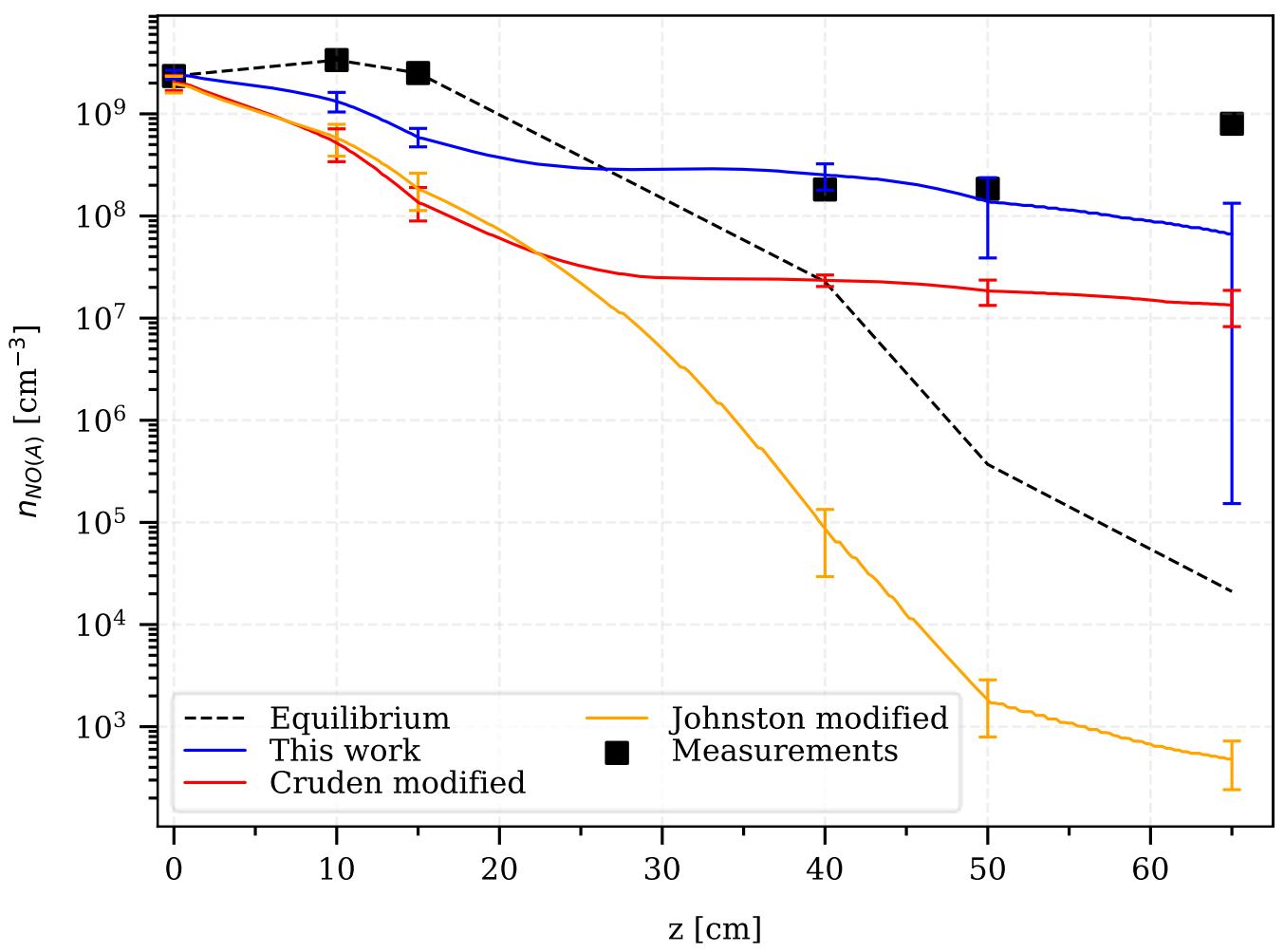

Figure 17 Densities of $\mathrm{NO}\left(\mathrm{A}^{2} \Sigma^{+}\right)$computed (lines) with updated Johnston's and Cruden's models compared to measured (black dots) and equilibrium (black diamonds) densities. 